\title{
Feeding dynamics of Acartia spp. copepods in a large, temperate estuary (San Francisco Bay, CA)
}

\author{
Gretchen C. Rollwagen Bollens*, Deborah L. Penry \\ Department of Integrative Biology, University of California at Berkeley, Berkeley, California 94720, USA
}

\begin{abstract}
We measured diet composition, prey preferences and feeding rates of Acartia spp., an abundant copepod group in San Francisco Bay. Monthly incubations with Acartia feeding upon the natural planktonic assemblage were conducted during spring 2000 at 2 locations: South Bay (SB, lagoonal estuary) and San Pablo Bay (SPB, partially mixed estuary). Prey assemblages in SB and SPB were always dominated by nanoplankton, however Acartia never consumed cells $<10 \mu \mathrm{m}$ in either location. Overall abundance $>15 \mu \mathrm{m}$ was always higher in $\mathrm{SB}$, comprised primarily of autotrophic cells (diatoms and pigment-containing flagellates). The assemblage in SPB was typically dominated by heterotrophic prey (ciliates and small non-pigmented flagellates). Acartia consumed a diverse diet but were highly selective for motile prey, especially ciliates and nanoflagellates. Acartia selectivity for individual prey taxa was strongest during periods of high food abundance, consistent with optimal foraging theory. In SB at least $50 \%$ of Acartia diet consisted of autotrophic biomass (diatoms, flagellates and the autotrophic ciliate Mesodinium). Ingestion rates were low and accounted for only $6.3 \%$ of body carbon per day, except during the March bloom, when Acartia ingested diatom biomass at $217 \mathrm{ng} \mathrm{C}$ copepod $^{-1} \mathrm{~h}^{-1}$, or $188 \%$ of body carbon per day. In SPB Acartia diets were dominated by heterotrophic prey $>10 \mu \mathrm{m}$, with ciliates and non-pigmented flagellates always $>60 \%$ of total biomass consumed. Ingestion rates were lower than in SB (typically equivalent to $2.2 \%$ of body carbon per day), but in the April bloom Acartia increased consumption of heterotrophic flagellates to $121 \mathrm{ng} \mathrm{C}$ copepod $^{-1} \mathrm{~h}^{-1}$, or $101 \%$ of body carbon per day. These results indicate that protozoans provide an essential nutritional supplement for San Francisco Bay copepods, especially in SPB, and that bloom periods may be important for copepod production and, in turn, higher trophic levels.
\end{abstract}

KEY WORDS: Copepod feeding $\cdot$ Acartia $\cdot$ Zooplankton $\cdot$ Ciliates $\cdot$ Clearance rates $\cdot$ Prey preference $\cdot$ Selectivity $\cdot$ San Francisco Bay

\section{INTRODUCTION}

The dominant paradigm of pelagic food web structure has historically held that copepods are the primary herbivores on autotrophic algae and in turn the main food source for adult and juvenile fish, thereby transferring energy directly from primary producers to higher trophic levels. However, more recently the linear food chain concept of diatoms-copepods-fish has been expanded to include the microbial community, and it generally acknowledges that copepods often consume a diverse diet that includes both autotrophic and heterotrophic prey.
This revision came about after improved sampling methods revealed the presence of a complex microbial food web in pelagic systems (Pomeroy 1974, Azam et al. 1983) and, in particular, high abundances of heterotrophic protists in a range of planktonic environments (Porter et al. 1985). Moreover, numerous recent field studies demonstrated that microzooplankton (heterotrophic/mixotrophic protists $<200 \mu \mathrm{m}$ ) consumed from 13 to $100 \%$ of primary productivity per day (e.g. Burkill et al. 1987, Strom \& Welchmeyer 1991, Verity et al. 1993, Landry et al. 1995, Tamigneaux et al. 1997, Lessard \& Murrell 1998, Edwards et al. 1999). In contrast, copepods rarely consumed $>30$ to $40 \%$ of daily 
phytoplankton production, even under bloom conditions (e.g. Bautista \& Harris 1992, Dagg 1993, Dam et al. 1993, 1995, Landry et al. 1994, Rollwagen Bollens \& Landry 2000). In addition to field evidence, several laboratory experiments showed that copepods ingested, and at times preferred, protozoans (i.e. ciliates) (Stoecker \& Egloff 1987, Wiadnyana \& Rassoulzadegan 1989).

As a result, many conceptual and quantitative models of planktonic food-web structure now include not only the potential for copepods to transfer materials and energy along the traditional planktonic chain, but also to form a trophic link between protozoan and metazoan food webs (E. B. Sherr et al. 1986, Stoecker \& Capuzzo 1990, Gifford 1991, Sanders \& Wickham 1993, Tett \& Wilson 2000, Halvorsen et al. 2001).

Consequently, a growing number of field investigations have been undertaken to directly measure the ingestion rates and diet composition of copepods feeding on natural assemblages of planktonic prey. Those studies conducted in the open and coastal ocean strongly support the revised concept of copepods as omnivores, often preferring heterotrophic prey (e.g. Gifford \& Dagg 1991, Kleppel 1992, Fessenden \& Cowles 1994, Kleppel et al. 1996, Verity \& Paffenhöfer 1996, Nejstgaard et al. 1997, Zeldis et al. 2002).

However, in estuaries, where the number of comparable investigations of copepod feeding preferences on non-algal prey is rather low, the results are less clear. For example, Gifford \& Dagg (1988) showed that Acartia tonsa in a small Louisiana estuary highly preferred ciliates over phytoplankton and consistently consumed microzooplankton carbon well out of proportion to its availability. But in a shallow, turbid estuary in SW France, Gasparini \& Castel (1997) found Eurytemora affinis and Acartia bifilosa to prefer autotrophic nanoplankton over heterotrophic cells. Considering that estuarine copepods are an important food resource for many commercially harvested fish species, greater examination of copepod feeding behavior in estuaries is especially meaningful.

San Francisco Bay is one of the largest coastal embayments on the US Pacific coast and a very important temperate estuary for both commercial and recreational fisheries. Copepods are the dominant mesozooplankton in the Bay (Ambler et al. 1985, Bollens et al. 2002) and are an important dietary resource for the larval and juvenile stages of several planktivorous fish species (Meng \& Orsi 1991, Moyle et al. 1992, Kurth \& Nobriga 2001). However, fish populations in San Francisco Bay have declined dramatically over the past decade (Bennett \& Moyle 1996), concurrent with significant reductions in the abundance of brackish water zooplankton populations (Orsi \& Mecum 1986, Obrebski et al. 1992, Jassby et al. 1995, Kimmerer \& Orsi 1996).
These declines are likely due to a combination of factors, including freshwater diversion, alteration of stream flows, loss of habitat, pollution, species introductions, and decreased primary and secondary productivity (reviewed in Bennett \& Moyle 1996). But with many fish species at risk in San Francisco Bay, quantitative information about copepod feeding rates and diet composition is crucial to defining the trophic pathways in the lower planktonic food web leading up to fish and higher trophic levels, and to understanding the causes of their reduced abundance.

No such data on copepod feeding behavior in San Francisco Bay existed prior to this study. Therefore, we had 2 major objectives: (1) to measure the diet composition, prey selectivity and feeding rates of Acartia spp. in 2 hydrographically distinct regions of San Francisco Bay: South Bay and San Pablo Bay; and (2) to compare how Acartia feeding behavior varied between the 2 locations over a wide range of prey availability. We conducted incubation experiments with copepods feeding upon the natural assemblage of $<200 \mu \mathrm{m}$ planktonic prey in South Bay and San Pablo Bay over a 4 mo period in 2000 that encompassed the spring elevation in water column chl a concentration. Acartia were selective feeders throughout the sampling period, often preferring large, heterotrophic prey, which has important consequences for the planktonic food web of San Francisco Bay and large, temperate estuaries more generally.

\section{MATERIALS AND METHODS}

Physical setting. San Francisco Bay is comprised of 2 major sub-estuaries, South Bay and San Pablo Bay, which connect via the Central Bay through the Golden Gate to the Pacific Ocean (Fig. 1). Both estuaries are wide and shallow (mean depth $=6 \mathrm{~m}$ ) and are incised by a narrow, relatively deep ( 15 m) channel, but each sub-estuary is characterized by a distinctly different set of hydrographic conditions (Conomos et al. 1985).

San Pablo Bay is a large embayment of the greater North Bay/Delta system, which from December to May receives considerable freshwater inflow due to rainfall and melt waters from the Sierra Nevada mountains, with much reduced freshwater input during the summer and fall. It thus acts as a partially mixed estuary through winter and spring, with short water-residence times and high turbidity (Cloern et al. 1985).

The seasonal pattern of phytoplankton biomass in San Pablo Bay prior to 1986 ranged from low levels in winter (1 to $3 \mu \mathrm{g} \mathrm{chl} \mathrm{a} \mathrm{l}^{-1}$ ) to high levels (>30 $\mu \mathrm{g} \mathrm{chl} \mathrm{a}$ $\mathrm{l}^{-1}$ ) during the spring/early summer bloom period, with low levels again in late summer and a brief increase in biomass in fall (Cloern et al. 1985). However, in 1986 
the successful invasion and rapid population growth of the Asian clam Potamocorbula amurensis throughout San Francisco Bay (Nichols et al. 1990) resulted in the elimination of the annual phytoplankton bloom in the northern reaches of the Bay (Alpine \& Cloern 1992). Hence, chl a levels in San Pablo Bay were consistently low through the 1990s. Recently, the abundance of benthic suspension feeders in San Pablo Bay has steadied or fallen somewhat (J. Thompson pers. comm.), and elevated phytoplankton biomass (>10 $\mu \mathrm{g}$ chl $a l^{-1}$ ) in the San Pablo Bay channel has been observed in late spring and early summer between 1998 and 2000 (Rollwagen Bollens \& Penry unpubl. data, US Geological Survey [USGS] Water Quality Monitoring Program available at http://sfbay.wr.usgs. gov/access/wqdata).

In contrast, South San Francisco Bay is a lagoon-type estuary with relatively homogeneous conditions throughout the water column due to more limited inputs of freshwater during the year. Water residence time is on the order of months, and turbidity is relatively low. However, in March or April of each year the combination of spring rainwater runoff, reduced tidal mixing and periods of relaxed winds produce water column stratification in the South Bay that effectively isolates the phytoplankton community from benthic

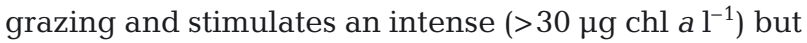
short-lived (3 to $5 \mathrm{wk}$ ) phytoplankton bloom. Despite the presence of Potamocorbula amurensis in South Bay, this pattern has been observed every year (Cloern 1991).

Copepod feeding experiments. As both bays experience a relatively predictable elevation of phytoplankton biomass in the late winter and spring, we used incubation experiments to measure Acartia prey preferences and ingestion rates over this period, to observe how copepod feeding changes over a wide range of prey abundance and taxonomic composition.

Copepods and prey for the experiments were collected from 2 stations in San Francisco Bay, 1 in South Bay and 1 in San Pablo Bay, corresponding to locations regularly visited by the USGS Water Quality Monitoring Program. For the last $30 \mathrm{yr}$, the USGS has measured a range of hydrographic parameters at numerous channel stations throughout the Bay and, in order to take advantage of this long-term set of accessory data, 2 USGS stations were chosen for our experiments: Stn 24 in South Bay $\left(37^{\circ} 41.9^{\prime} \mathrm{N}_{i} 122^{\circ} 20.3^{\prime} \mathrm{W}\right)$ and Stn 14 in San Pablo Bay $\left(38^{\circ} 0.4^{\prime} \mathrm{N}_{i} 122^{\circ} 24.3^{\prime} \mathrm{W}\right)$ (Fig. 1). We conducted 7 sets of experiments using copepods and prey from these stations between February and May 2000: 4 in South Bay (February 21, March 27, April 24 and May 26) and 3 in San Pablo Bay (February 28, April 24 and May 26). Profiles of temperature and salinity were obtained at each sampling station using a Seabird SBE19 CTD.

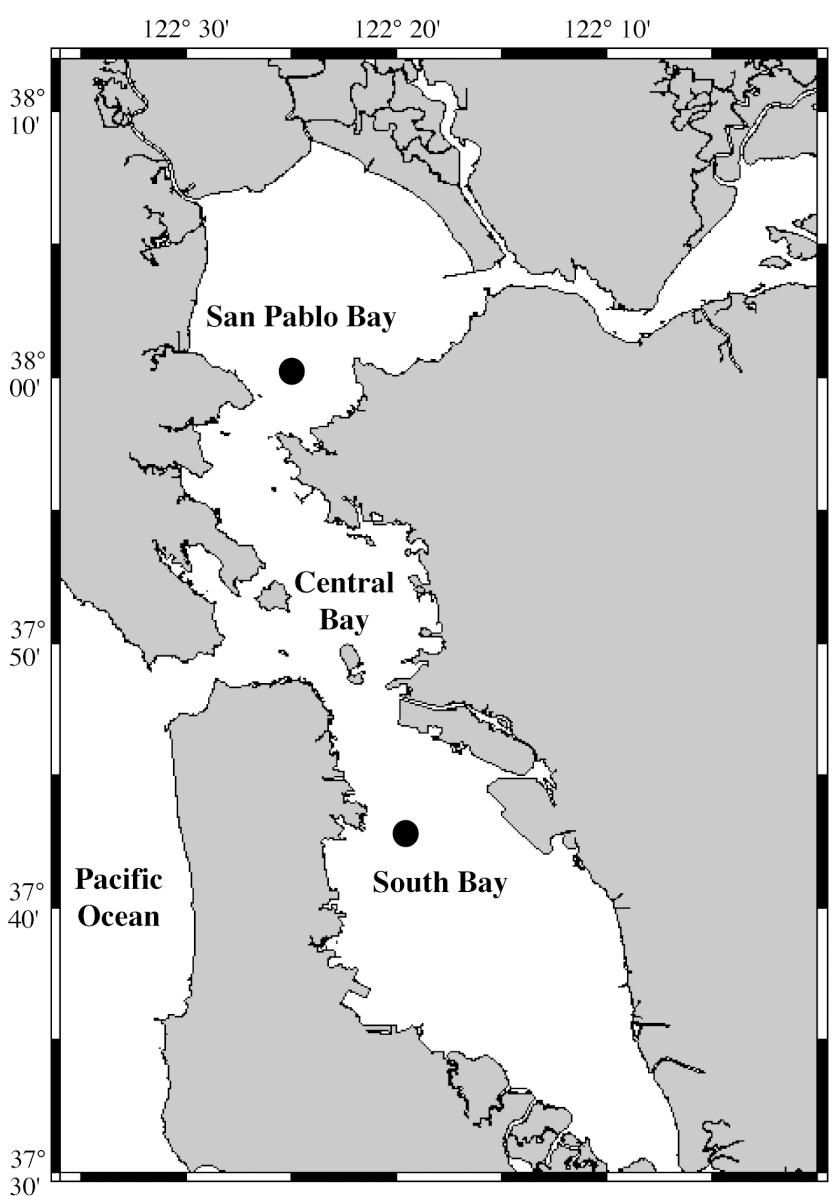

Fig. 1. Map of the San Francisco Bay estuary, CA, USA, showing station locations ( ) where copepods and prey were collected

Incubation experiments were conducted using adult, female Acartia feeding upon the natural assemblage of $<200 \mu \mathrm{m}$ planktonic prey. Acartia spp. comprises a suite of 2 sub-genera (Acartiura and Acanthacartia) and at least 3 species (A. tonsa, A. californiensis, Acartiura spp.) that co-occur throughout the saline ( $>10$ PSI) portions of San Francisco Bay. However, between February and May, the most common species are typically A. tonsa and Acartiura spp. (Ambler et al. 1985, S. M. Bollens unpubl. data). For simplicity, we refer to this species group as Acartia from this point further. Acartia has historically been the most abundant copepod group in these regions, although a number of small copepod species (e.g. Limnoithona tetraspina, Oithona similis) have recently invaded the northern reaches of the Bay and are now among the numerical dominants (Bollens et al. 2002).

The feeding experiments followed a modified protocol as described by Gifford \& Dagg (1988). Copepods for the incubations were collected using a $202 \mu \mathrm{m}$, 
$0.5 \mathrm{~m}$ diameter plankton net suspended for 10 to 20 min at $\sim 3$ m depth (in South Bay) or $12 \mathrm{~m}$ depth (in San Pablo Bay) as the vessel drifted. Concurrently, a 101 Niskin bottle equipped with interior teflon springs was used to capture water containing the natural assemblage of prey at the same depth as the copepods were collected. The water column in South Bay was relatively well mixed during each sampling period so experimental animals and prey were collected nearer the surface. However, in San Pablo Bay the water column was stratified during this period, with a lowsalinity, seaward-flowing layer at the surface and a higher-salinity, landward-flowing layer at depth. Therefore, the plankton net and water bottle were deployed at depth in order to sample the high-salinity layer where Acartia is found.

For all experiments, unscreened natural seawater containing the planktonic assemblage was gently siphoned from the Niskin bottles through silicone tubing into $500 \mathrm{ml}$ polycarbonate incubation bottles aboard ship. Triplicate incubation bottles were filled as initial and final controls (natural nano-/microplankton assemblage only) and for the final treatments (assemblage plus copepods). All bottles and plankton were kept chilled and returned to the laboratory within $3 \mathrm{~h}$.

In the laboratory, adult female Acartia were sorted from the plankton samples in dim light, transferred to holding beakers containing unfiltered seawater and kept at the experimental temperature. After $\sim 4$ to $6 \mathrm{~h}$, 25 copepods were added to each treatment bottle to begin the experimental incubations. The final control and treatment bottles were completely topped off with unscreened natural seawater, covered in Parafilm and sealed to eliminate bubbles. The bottles were then mounted on a plankton wheel rotating at $1 \mathrm{rpm}$ in a temperature-controlled room set to match the ambient conditions $\left(\sim 15\right.$ to $\left.18^{\circ} \mathrm{C}\right)$. Two incubations per experiment were performed: over $12 \mathrm{~h}$ from 20:00 to 08:00 $\mathrm{h}$ the next morning (in darkness), and over $24 \mathrm{~h}$ from 20:00 to 20:00 $\mathrm{h}$ the next evening (12:12 $\mathrm{h}$ dark:light).

Cell counts and biomass estimations. The initial control bottles were subsampled for microplankton (15 to $200 \mu \mathrm{m})$ and nanoplankton $(\sim 5$ to $15 \mu \mathrm{m})$ at the beginning of each experiment; the remaining incubation bottles (final controls and treatments) were similarly subsampled after the 12 and $24 \mathrm{~h}$ incubations. The $15 \mu \mathrm{m}$ threshold was used to distinguish microplankton and nanoplankton, rather than the typical operational size boundary of $20 \mu \mathrm{m}$, based on the size distribution of organisms in the natural assemblage. In addition, all taxa with individual cell size $<15 \mu \mathrm{m}$ were considered nanoplankton, even though some diatom genera (such as Skeletonema and Chaetocerus) often form chains that could be long enough to be perceived as microplankton by grazers. We chose to label these as nanoplankton since abundance was measured on individual cell counts.

In order to enumerate and identify the microplankton, a $200 \mathrm{ml}$ subsample from each incubation bottle was preserved in $10 \%$ acid Lugol's solution, then stored in the dark at $12^{\circ} \mathrm{C}$ until analyzed. Samples were processed within 9 mo of preservation. Aliquots of 25 to $50 \mathrm{ml}$ from each bottle were settled overnight in Utermohl chambers, and the entire contents of the chamber between 15 and $200 \mu \mathrm{m}$ enumerated using an inverted microscope at $200 \times$ magnification. A minimum of 100 cells were counted per sample, identified to genus, and grouped into one of the following major prey categories: loricate ciliates, aloricate ciliates, diatoms, dinoflagellates, or autotrophic microflagellates. Each cell was measured using the ocular micrometer, and biovolume calculated according to geometric shape (Wong \& Cloern 1982). A conversion of 0.35 cell: lorica volume was used to estimate loricate ciliate biovolume, based on direct measurements of $>100$ individuals over a range of taxa, times, and locations within each bay (data not shown). Carbon biomass was then estimated using the biovolume-biomass conversions of Menden-Deuer \& Lessard (2000).

In the analyses, all ciliates were considered to be heterotrophic, except the autotrophic aloricate ciliate Mesodinium rubrum (Crawford 1989). Based on studies of protozoan feeding in Chesapeake Bay (Dolan 1991) and other work reviewed in Nejstgaard et al. (2001b), the ciliate taxa present in San Francisco Bay most likely ingest bacterial, algal or flagellate prey, even though some may also contain chloroplasts.

For nanoplankton enumeration, an additional $100 \mathrm{ml}$ subsample from each incubation bottle was preserved in $1 \%$ glutaraldehyde, from which $2 \times 20 \mathrm{ml}$ aliquots were stained with fluorescein isothiocyanate (FITC), filtered onto $1.0 \mu \mathrm{m}$ black polycarbonate filters, and mounted on glass slides (Sherr et al. 1993). The slides were kept frozen until analysis (within $6 \mathrm{mo}$ ). In order to enumerate the nanoplankton, a minimum of 100 cells between 5 and $15 \mu \mathrm{m}$ were counted using an epifluorescence microscope at 400 to $450 \times$ magnification. Only cells larger than $5 \mu \mathrm{m}$ were included since Acartia typically are unable to efficiently handle and ingest cells smaller than this size (Nival \& Nival 1976). Cells were sized and grouped into 3 major categories: nanodiatoms, autotrophic nanoflagellates, or heterotrophic nanoflagellates (based on the presence or absence of chlorophyll autofluorescence within the cell). Nanoplankton carbon biomass was estimated from biovolume as described for microplankton.

Feeding rates and selectivity. Feeding incubations were carried out for 12 and $24 \mathrm{~h}$ in all experiments. However, since changes to the community composition in all experiments were significant after $12 \mathrm{~h}$, we view 
the shorter incubation period as the best representation of how Acartia responded to the initial, ambient prey assemblage. Therefore, only the $12 \mathrm{~h}$ incubation results were used to measure Acartia feeding rates. Clearance rates $\left(\mathrm{ml} \mathrm{copepod}^{-1} \mathrm{~h}^{-1}\right)$ and ingestion rates (cells copepod ${ }^{-1} \mathrm{~h}^{-1}$ and $\mathrm{ng} \mathrm{C}$ copepod ${ }^{-1} \mathrm{~h}^{-1}$ ) of Acartia were calculated using the equations of Marin et al. (1986).

Feeding selectivity and prey preferences of Acartia were then assessed in 2 ways: first, by comparing the distribution of prey types in Acartia diet with their distribution in the available medium in each experiment using $\chi^{2}$ goodness-of-fit tests (Zar 1996). Significant $(\mathrm{p}<0.05)$ differences between these distributions was interpreted as selective feeding by the copepod predators. The second measure of feeding preference was a comparison of clearance rates and electivity indices $\left(E^{*}\right.$, Vanderploeg \& Scavia 1979a,b) for the major prey categories consumed within each experiment, using Kruskal-Wallis ANOVA by ranks (Zar 1996). Acartia preferences for individual taxa were also assessed by calculating electivity indices for all taxa representing $>2 \%$ of total microplankton abundance in each experimental incubation.

Clearance rate is a traditional measure of selectivity by suspension-feeding plankton, since the calculation is based on the ratio of the prey abundance remaining in a treatment bottle to initial abundance (with modification for cell growth in the controls without grazers). However, since the calculations involve taking the natural logarithm of this ratio, clearance rate can only be determined if the abundance of prey remaining at the end of a feeding incubation is greater than zero. Natural planktonic assemblages are characterized by many different individual taxa present over a wide range of relative abundance; thus, these experiments often resulted in some prey taxa being completely consumed. Clearance rates could not be calculated for these individual taxa, resulting in a biased and inaccurate description of predator preferences. Moreover, clearance rates were sometimes negative when prey growth in the controls exceeded grazing losses in the treatments with predators.

Therefore, in addition to using clearance rate as a measure of copepod prey preference, the preference of Acartia for different types of prey during each experiment was estimated using $\mathrm{E}^{*}$ (Vanderploeg \& Scavia 1979a,b). Of the several electivity indices described in the literature, in particular Chesson's $\alpha$ (Chesson 1983) and Ivlev's E (Ivlev 1961), $\mathrm{E}^{*}$ is the most appropriate for this sort of feeding experiment. As reviewed by Lechowicz (1982) and Confer \& Moore (1987), $\mathrm{E}^{*}$ is the only index sufficiently stable to accommodate both changes in relative abundance of food types and the presence of rare prey types.
While $\mathrm{E}^{*}$ does not allow for parametric statistical analyses, it does allow for a meaningful rank-order comparison of electivities from diverse sites and sampling periods.

$\mathrm{E}^{*}$ ultimately compares the proportion of a particular prey type in the available medium with the proportion of that prey type in the predator's diet. To estimate $\mathrm{E}^{*}$, several calculations were made. First, the number of individuals of each prey type consumed by the copepods $\left(R_{\mathrm{i}}\right)$ in each experiment was determined as follows:

$$
R_{\mathrm{i}}=\frac{\left(N_{\mathrm{ic}}+N_{\mathrm{fc}}\right)}{2}-N_{\mathrm{ft}}
$$

where i was the prey item, $N_{\text {ic }}$ was the mean number of individuals present in the initial bottles, $N_{\mathrm{fc}}$ was the mean number of individuals present in the control bottles at the end of the incubation, and $N_{\mathrm{ft}}$ was the mean number of individuals present in each treatment bottle at the end of the incubation. The proportion of each prey type in the diet $\left(r_{\mathrm{i}}\right)$ and in the available medium $\left(n_{\mathrm{i}}\right)$ were then further calculated as:

$$
r_{\mathrm{i}}=\frac{R_{\mathrm{i}}}{\sum_{\mathrm{j}=1}^{\mathrm{m}} R_{\mathrm{j}}}
$$

and

$$
n_{\mathrm{i}}=\frac{N_{\mathrm{ic}}}{\sum_{\mathrm{j}=1}^{m} N_{\mathrm{jc}}}
$$

where $m$ was the number of prey types, and $R_{\mathrm{i}}$ and $N_{\mathrm{ic}}$ were as described above.

$\mathrm{E}^{*}$ for each prey type was calculated according to the formula below:

$$
E_{i}^{*}=\frac{W_{i}-\frac{1}{m}}{W_{i}+\frac{1}{m}}
$$

where $W_{\mathrm{i}}$ was defined by the following equation:

$$
W_{\mathrm{i}}=\frac{\frac{r_{\mathrm{i}}}{n_{\mathrm{i}}}}{\sum_{\mathrm{j}=1}^{m} \frac{r_{\mathrm{i}}}{n_{\mathrm{i}}}}
$$

Neutral preference was indicated by an $\mathrm{E}^{*}$ of 0 , with positive values up to +1 representing increasing preference and negative values down to -1 representing increasing avoidance.

Feeding rates and prey selectivity were determined for only those prey categories that met the following criteria. When the total abundance of either size fraction in an experiment (microplankton or nanoplankton) showed a significant reduction in cell numbers between the control 


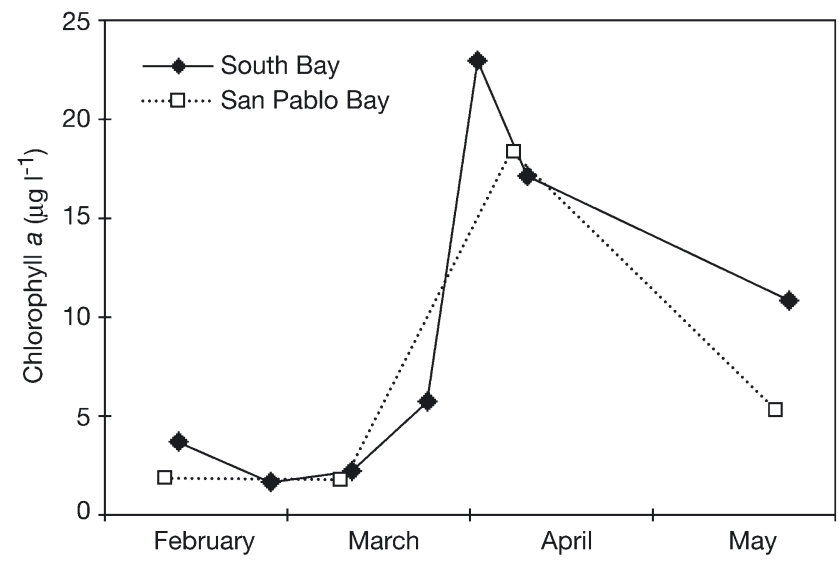

Fig. 2. Chl a concentration in South Bay (3 m) and San Pablo Bay (9 to $10 \mathrm{~m}$ ) between February and May 2000. (Data courtesy of US Geological Survey Water Quality Monitoring Program, available at http://sfbay.wr.usgs.gov/access/wqdata)

and treatment bottles at the end of an incubation $(\mathrm{p}<$ 0.05, using $t$-tests assuming unequal variances, Zar 1996), then the rates and electivities for all major prey categories in that size fraction were included in further analyses. If there was no significant reduction in total cell abundance between final control and treatment bottles within a size fraction, then only those major categories of prey that individually showed a significant reduction were also included.

\section{RESULTS}

\section{Prey abundance, biomass and composition}

Elevations in phytoplankton biomass occurred during early April 2000 in both South Bay and San Pablo Bay, with chl a levels reaching a peak of $18.4 \mu \mathrm{g} \mathrm{chl} \mathrm{a} \mathrm{l}^{-1}$ in South Bay (at $3 \mathrm{~m}$ ) and $14.7 \mu \mathrm{g} \mathrm{chl} \mathrm{al^{-1 }}$ in San Pablo Bay (at 9 to $10 \mathrm{~m}$ ) (Fig. 2). In both South Bay and San Pablo Bay, the abundance and carbon biomass of the $<200 \mu \mathrm{m}$ assemblage were dominated by cells in the nanoplankton size range, with abundances of nanoplankton typically 3 orders of magnitude higher than microplankton. Also, in both bays diatoms generally showed the greatest increases in abundance and biomass during the chl a peaks. However, there were substantial differences in the overall patterns of change in abundance, biomass and taxonomic composition of the $<200 \mu \mathrm{m}$ community between the 2 bays.
South Bay

Microplankton. Total microplankton (15 to $200 \mu \mathrm{m})$ abundance and biomass was consistently higher in South Bay relative to San Pablo Bay, often by as much as 3 -fold (Figs. $3 \& 4$ ), and the relative proportions of the major microplanktonic groups (ciliates, diatoms and dinoflagellates) in each Bay differed as chl a concentration sharply increased and then declined.

In February, prior to the chl a peak, ciliate abundance and biomass in South Bay was approximately equal to that of diatoms, and dinoflagellates were nearly absent. Large, loricate ciliates, including Tintinnopsis and Codonellopsis, peaked in biomass early in the period of rising chl $a$, with a 10-fold increase in late March over their winter levels, and then fell back to near pre-bloom levels in April and May (Fig. 3). Conversely, the large, centric diatom genera Coscinodiscus and Thalassiosira reached their highest biomass levels in late April, after water column chl a had reached its maximum and begun to decline. In late May, chl a levels were still at moderate levels, but diatom biomass had decreased by more than half from

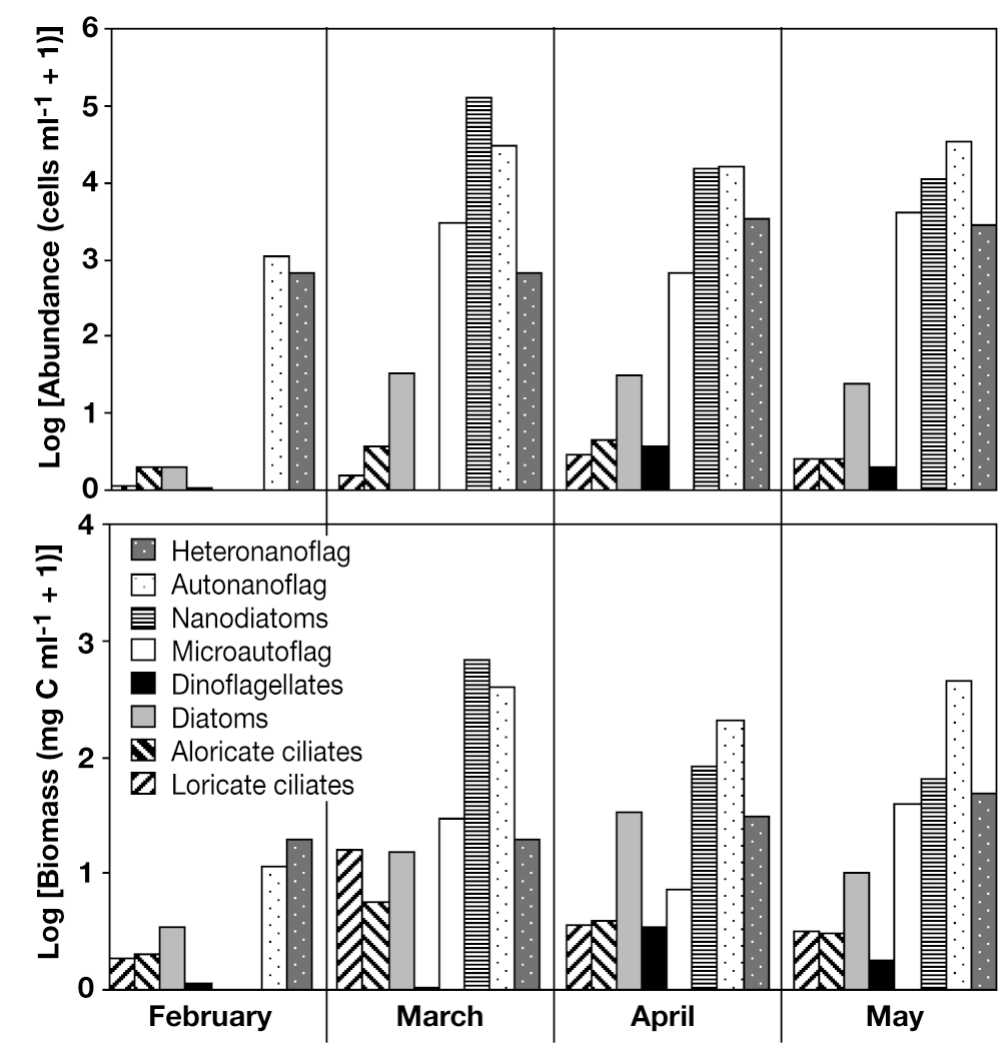

Fig. 3. Initial abundance and biomass of plankton $<200 \mu \mathrm{m}$ in size from South Bay between February and May 2000. Microautoflag = autotrophic flagellates 15 to $20 \mu \mathrm{m}$; Nanodiatoms = diatoms $<15 \mu \mathrm{m}$; Autonanoflag $=$ autotrophic flagellates $<15 \mu \mathrm{m}$; Heteronanoflag $=$ heterotrophic flagellates $<15 \mu \mathrm{m}$ in size 
its April maximum. Dinoflagellate abundance and biomass peaked in April, at triple the amount present in February, and then fell to moderate concentrations in May. Small (15 to $20 \mu \mathrm{m}$ ) autotrophic flagellates also increased dramatically in March, decreased somewhat in April and were again high in May (Fig. 3).

Nanoplankton. Before the chl a maximum, nanoplankton (5 to $15 \mu \mathrm{m}$ ) abundance and biomass were at their lowest levels, and nanoplanktonic diatoms were nearly completely absent (Fig. 3). However, in late March as chl a levels were beginning to rise, the small (5 to $8 \mu \mathrm{m} \mathrm{cell}{ }^{-1}$ ), chain-forming diatom Skeletonema spp. increased by over 5 orders of magnitude to $\sim 10^{5}$ cells $\mathrm{ml}^{-1}$. Interestingly, abundance and biomass of small diatoms decreased in South Bay during April, when larger microplanktonic diatoms were at their maximum concentrations, while autotrophic flagellates remained at relatively high abundance throughout March, April and May. Heterotrophic flagellates showed only slight variations in abundance and biomass throughout the sampling period from February to May, despite the dramatic changes in autotrophic biomass (Fig. 3).

\section{San Pablo Bay}

Microplankton. Among the microplanktonic community in San Pablo Bay prior to the elevation in chl a concentration, ciliates represented $\sim 51 \%$ of total abundance but $>75 \%$ of the total biomass, made up of species mainly from the genera Tintinnopsis, Eutintinnus, Mesodinium and Strombidium. Diatoms (chiefly Coscinodiscus) and dinoflagellates (Ceratium, Protoperidinium, and Gymnodinium) made up equal proportions of the remaining assemblage. During the peak in chl a in April, both large diatoms and loricate ciliates increased by an order of magnitude over their pre-bloom levels. In late May, water column chl a concentration was again low, and overall ciliate biomass decreased by half from its peak in April. However, diatom biomass remained constant after the chl a peak as chains of small Thalassiosira cells increased in abundance (Fig. 4).

Nanoplankton. Similar to the pattern in South Bay, a substantial bloom of Skeletonema diatoms during April raised nanoplanktonic diatom abundance to more than $6 \times 10^{5}$ cells $\mathrm{ml}^{-1}$. Abundance and biomass of nanoplanktonic diatoms then fell dramatically during May, as chl a levels returned to winter levels. Autotrophic and heterotrophic flagellate biomass remained relatively stable at high levels throughout April and May (Fig. 4). Unfortunately, due to filtering problems, the February nanoplankton subsamples from San Pablo Bay could not be enumerated. However, low nanoplankton abundance and biomass in May 2000, as well as low levels measured from the same location in February 1998 (G. C. Rollwagen Bollens unpubl.), suggest that nanoplankton abundance and biomass were likely low in February 2000, just as was observed in South Bay (Fig. 3).

\section{Prey selectivity and ingestion rates}

Throughout the 4 mo sampling period in both bays, Acartia demonstrated strongly selective feeding behavior as measured by highly significant ( $\mathrm{p} \ll 0.001$ ) differences in the distributions of prey items in their diet compared to the distributions of prey available in the feeding medium. Moreover, Acartia never consumed prey $<10 \mu \mathrm{m}$ in size and often preferred prey

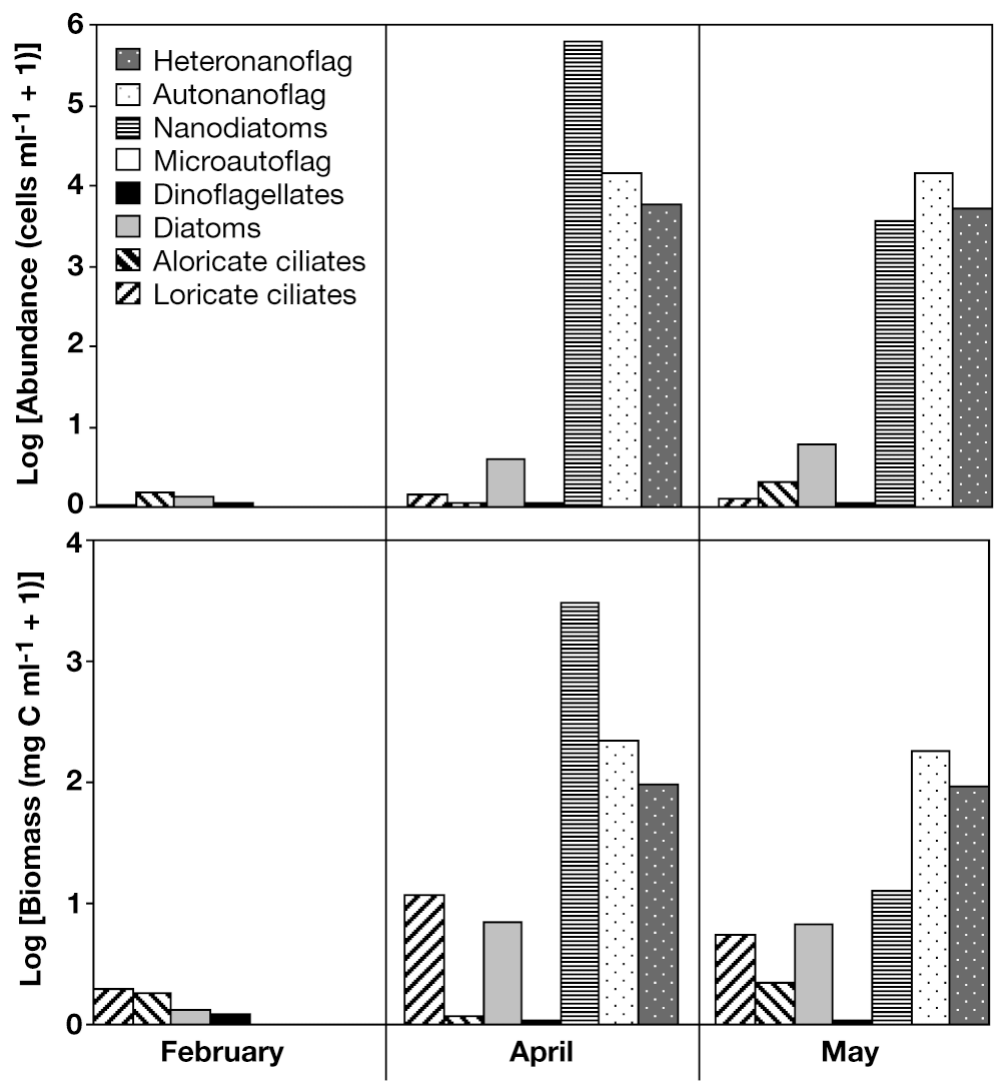

Fig. 4. Initial abundance and biomass of plankton $<200 \mu \mathrm{m}$ in size from San Pablo Bay between February and May 2000. Definition of prey categories as in Fig. 3 
$>25 \mu \mathrm{m}$, despite the prey field being dominated by nanoplankton cells (5 to $15 \mu \mathrm{m}$ ). Acartia also showed significant preferences for particular categories of prey among those consumed in South Bay, but did not show significant preferences for any major prey category in San Pablo Bay.

\section{South Bay}

Selection for major prey categories. During all experiments selective ingestion of prey cells resulted in highly significant differences $(\mathrm{p} \ll 0.001)$ in both the abundance and biomass of each prey category in Acartia diet relative to that available (Fig. 5). From February through May, nanoplankton cells dominated the
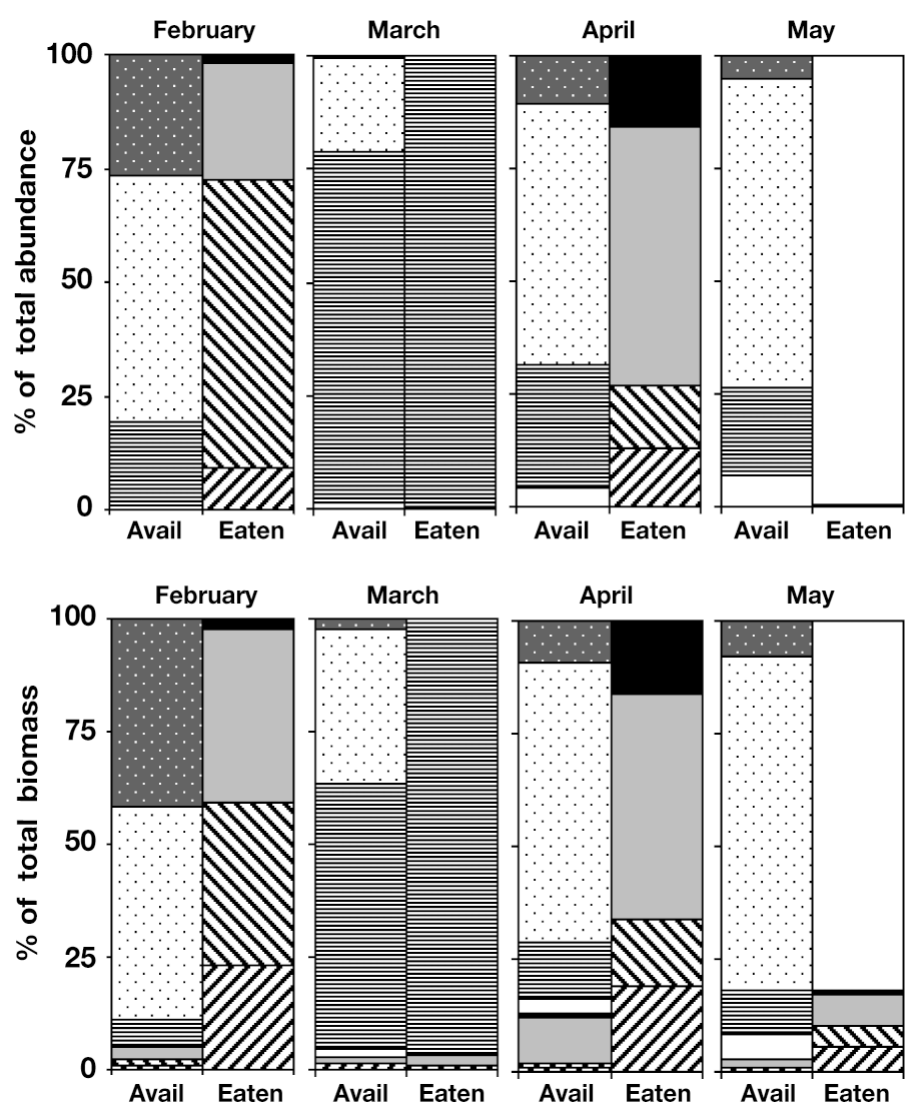

Heteronanoflag

$\square$ Autonanoflag
ㅌ Nanodiatoms
$\square$ Microautoflag

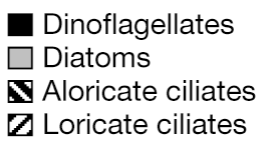

Fig. 5. Relative abundance and biomass of prey categories available vs. eaten by Acartia spp. during $12 \mathrm{~h}$ incubations with unfiltered seawater from South Bay between February and May 2000. Definition of prey categories as in Fig. 3. Avail $=\%$ of total prey biomass available during incubation; Eaten $=\%$ of total prey biomass consumed during incubation field of available prey. However, except in March, when Acartia consumed almost exclusively Skeletonema diatom chains, Acartia strongly selected for individual prey cells larger than $15 \mu \mathrm{m}$.

In February, when microplanktonic diatoms and ciliates were in roughly equal abundance and together only accounted for $<1 \%$ of the available prey, nearly $75 \%$ of Acartia diet abundance was comprised of loricate and aloricate ciliates. In March, the chain-forming diatoms Skeletonema accounted for $\sim 80 \%$ of the prey available, but were $>99 \%$ of the total abundance of prey items in the Acartia diet. As the Skeletonema bloom disappeared in April, Acartia consumed a higher proportion of diatoms and dinoflagellates than in February or March. By May, despite continued dominance of the available prey by nanoplankton cells, Acartia showed very strong selection for 15 to $20 \mu \mathrm{m}$ sized autotrophic flagellates (Fig. 5).

In addition to selecting larger cells over the dominant nanoplankton, Acartia also demonstrated preferences for particular categories of prey, as measured by significant differences between clearance rate and/or electivity index for the major prey categories consumed (Fig. 6). In February, there were no significant $(p>0.05)$ differences among either clearance rates or electivity indices for the major prey categories, indicating that no single major prey category consumed was preferred over the other. However, as Skeletonema diatoms bloomed in March, Acartia showed significantly positive electivity for dinoflagellates over the other prey categories $(\mathrm{p}=0.039)$. The clearance rate for diatoms $>15 \mu \mathrm{m}$ was also significantly higher than that for nanoplanktonic diatoms in March $(\mathrm{p}=$ 0.026). Dinoflagellates were in low relative abundance, but were completely consumed in the incubations. This precluded calculating clearance rates for dinoflagellates, but it can be assumed that feeding rates on these prey would therefore have been high as well (Fig. 6).

Acartia preferred large loricate ciliates in April, with significantly positive electivity for this category, while electivity for microplanktonic diatoms was significantly negative $(p=0.019)$. Also in April, the clearance rate for loricate ciliates was significantly higher than for aloricate ciliates. Clearance of loricate ciliates was not significantly different from clearance of dinoflagellates, but both were significantly higher than the clearance rate for diatoms $>15 \mu \mathrm{m}$. Finally, in May both measures of preference showed significant differences among prey categories (clearance rate $\mathrm{p}=0.042$; electivity $\mathrm{p}=0.014)$, when Acartia shifted preference toward 15 to $20 \mu \mathrm{m}$ autotrophic flagellates. Electivity for this size category of autotrophic flagellates was significantly positive, and clearance rate of these flagellates was significantly higher than clearance of both 
microplanktonic diatoms and dinoflagellates (Fig. 6).

Preference for individual prey taxa. The pattern of electivity for individual taxa present in South Bay also suggests that Acartia was a highly selective feeder, especially when overall prey abundance was high (Table 1). Acartia often preferentially consumed specific prey genera (usually removing all cells of that type from the experimental enclosure), even when other prey of the same functional or taxonomic group were present in higher numbers.

In February, when the assemblage was relatively equally distributed among ciliates and diatoms, Acartia particularly targeted $>30 \mu \mathrm{m}$ diameter Protoperidinium (a dinoflagellate), Thalassiosira (a diatom) and large (>30 $\mu \mathrm{m}$ ) Strombidium (an aloricate ciliate). In March, while chains of Skeletonema diatoms were in very high abundance, along with small (15 to $20 \mu \mathrm{m})$ autotrophic flagellates, Acartia preferentially consumed large centric diatoms (Coscinodiscus $>100 \mu \mathrm{m}$ diameter, Thalassiosira $>25 \mu \mathrm{m})$ and Strombilidium (aloricate ciliate). Small $(<15 \mu \mathrm{m})$ diatoms were still in very high abundance in April and May, but Acartia continued to show preference for larger cells. In April, Acartia selected $>30 \mu \mathrm{m}$ Mesodinium (autotrophic ciliate). In May, Acartia shifted preference toward the cells in highest abundance, i.e. small (15 to $20 \mu \mathrm{m})$ autotrophic flagellates, but also maintained a preference for aloricate ciliates (Halteria and Strombidinopsis) (Table 1).

Ingestion rates. There were significant differences in mean ingestion rates (cells copepod ${ }^{-1} \mathrm{~h}^{-1}$ ) of Acartia upon the major prey categories in February $(p=0.027)$, March ( $p=0.026)$ and May $(p=0.034) 2000$, but not in April ( $p>0.05)$. In February, loricate ciliates, aloricate ciliates and diatoms were all ingested at rates between 0.99 and $1.6 \mathrm{ng} \mathrm{C}$ copepod $^{-1} \mathrm{~h}^{-1}$. When Skeletonema diatoms bloomed in March, Acartia dramatically increased their ingestion and consumed nanoplanktonic diatom biomass at $220 \mathrm{ngC}$ copepod $^{-1} \mathrm{~h}^{-1}$ and microplanktonic diatoms at $6.3 \mathrm{ngC}$ copepod $^{-1} \mathrm{~h}^{-1}$ (Fig. 6). Mean ingestion rates on the major prey categories were all comparatively low $(<4.0 \mathrm{ng} \mathrm{C}$ cope$\operatorname{pod}^{-1} \mathrm{~h}^{-1}$ ) in April but increased again in May when Acartia targeted the small autotrophic flagellates (90 ng C copepod ${ }^{-1} \mathrm{~h}^{-1}$ ). (Note that in 2 of the 3 replicate final treatment bottles for the May experiment, no 15 to $20 \mu \mathrm{m}$ autotrophic flagellates were observed in the microscopical counts, which made it impossible to calculate clearance rate and ingestion rate for this prey category in those replicates.)

\section{San Pablo Bay}

Selection for major prey categories. In San Pablo Bay, there were highly significant $(\mathrm{p} \ll 0.001)$ differences between the frequency distributions of prey categories in the surrounding medium and prey categories in Acartia diet in April and May. These results indicate selective feeding by Acartia. The distributions were not significantly different $(p>0.05)$ in February; however, filtering problems prevented the enumeration of nanoplankton in this experiment, and thus could not be included in the statistical analyses.

In San Pablo Bay, heterotrophic prey biomass was most often consumed (Fig. 7), unlike in South Bay, where Acartia consumed primarily autotrophic prey 
Table 1. Individual taxa representing $>2 \%$ of total prey consumed by Acartia spp. during $12 \mathrm{~h}$ incubations with unfiltered seawater from South Bay between February and May 2000. Avail $=\%$ of total prey biomass available during incubation; Eaten $=\%$ of total prey biomass consumed during incubation; $\mathrm{E}^{*}=$ mean $( \pm 1 \mathrm{SE})$ electivity index for that prey taxon during incubation. Positive $E^{*}$ : preference, negative $E^{*}$ : avoidance. Bold indicates $E^{*}$ significantly different from zero, with ${ }^{*} p<0.05$, ${ }^{* *} p<0.025$,

$$
{ }^{* * *} \mathrm{p}<0.01
$$

\begin{tabular}{|c|c|c|c|c|c|c|c|c|c|c|c|c|}
\hline \multirow{3}{*}{$\begin{array}{l}\text { Prey type } \\
\text { Loricate ciliates }\end{array}$} & \multicolumn{3}{|c|}{$\longrightarrow$ February $\longrightarrow$} & \multicolumn{3}{|c|}{ March $\longrightarrow$} & \multicolumn{3}{|c|}{$\longrightarrow$ April $\longrightarrow$} & \multirow{2}{*}{\multicolumn{2}{|c|}{$\overline{\text { Avail Eaten }}$}} & \multirow[b]{2}{*}{$\mathrm{E}^{*}$} \\
\hline & \multirow[t]{2}{*}{ Avail } & Eaten & \multirow[t]{2}{*}{$E^{*}$} & \multirow[t]{2}{*}{ Avail } & \multicolumn{2}{|c|}{ Eaten $\quad E^{*}$} & \multirow[t]{2}{*}{ Avail } & \multicolumn{2}{|c|}{ Eaten $\quad E^{*}$} & & & \\
\hline & & & & & & & & & & & & \\
\hline $\begin{array}{l}\text { Tintinnopsis } \\
(70 \mu \mathrm{m})\end{array}$ & 15.4 & 8.8 & $-0.51(0.32)$ & & & & & & & & & \\
\hline $\begin{array}{l}\text { Tintinnopsis } \\
(35 \mu \mathrm{m})\end{array}$ & 1.2 & 0.6 & $-0.05(0.47)$ & & & & 5.0 & 17.7 & $-0.25(0.38)$ & 1.4 & 0.9 & $-0.06(0.13)$ \\
\hline Aloricate ciliates & & & & & & & & & & & & \\
\hline $\begin{array}{l}\text { Strombidium } \\
(15-25 \mu \mathrm{m})\end{array}$ & 1.3 & 0.7 & $-0.44(0.14)^{*}$ & 0.0 & 0.0 & $-0.36(0.37)$ & 0.2 & 0.6 & $0.20(0.14)$ & 0.1 & 0.1 & $0.01(0.06)$ \\
\hline $\begin{array}{l}\text { Strombidium } \\
(25-50 \mu \mathrm{m})\end{array}$ & 9.7 & 18.2 & $0.17(0.07)^{*}$ & 0.0 & 0.0 & $-0.59(0.41)$ & 1.9 & 5.0 & $0.04(0.11)$ & 0.6 & 0.5 & $0.06(0.08)$ \\
\hline $\begin{array}{l}\text { Halteria } \\
(10-20 \mu \mathrm{m})\end{array}$ & 0.2 & 0.2 & $-0.23(0.39)$ & 0.0 & 0.0 & $0.16(0.26)$ & 0.7 & 2.3 & $-0.29(0.35)$ & 0.0 & 0.1 & $0.28(0.02)^{* * *}$ \\
\hline $\begin{array}{l}\text { Mesodinium } \\
(20-30 \mu \mathrm{m})\end{array}$ & 2.7 & 2.8 & $-0.24(0.36)$ & 0.0 & 0.0 & $-0.94(0.06)^{* * *}$ & 1.7 & 2.0 & $-0.40(0.36)$ & 0.8 & 0.1 & $-0.68(0.22)^{*}$ \\
\hline $\begin{array}{l}\text { Mesodinium } \\
(30-40 \mu \mathrm{m})\end{array}$ & 5.3 & 9.7 & $-0.04(0.35)$ & 0.1 & 0.1 & $0.11(0.56)$ & 0.1 & 0.3 & $0.43(0.09)^{*}$ & 0.1 & 0.0 & $-0.58(0.42)$ \\
\hline $\begin{array}{l}\text { Strombilidium } \\
(30-50 \mu \mathrm{m})\end{array}$ & 3.1 & 1.5 & $-0.48(0.26)$ & 0.0 & 0.1 & $0.52(0.07)^{* *}$ & 0.1 & 0.0 & $-0.05(0.49)$ & & & \\
\hline $\begin{array}{l}\text { Strombidinopsis } \\
(60-70 \mu \mathrm{m})\end{array}$ & 1.5 & 0.2 & $-0.58(0.42)$ & 0.1 & 0.2 & $0.04(0.53)$ & 1.3 & 4.5 & $-0.10(0.45)$ & 1.9 & 2.6 & $0.34(0.06)^{* *}$ \\
\hline Diatoms & & & & & & & & & & & & \\
\hline $\begin{array}{l}\text { Coscinodiscus } \\
(30-50 \mu \mathrm{m})\end{array}$ & 2.8 & 0.9 & $-0.60(0.24)$ & 0.5 & 0.5 & $0.47(0.02)^{* * *}$ & 3.7 & 2.6 & $-0.82(0.18)^{* *}$ & 4.2 & 0.7 & $-0.60(0.06)^{* * *}$ \\
\hline $\begin{array}{l}\text { Coscinodiscus } \\
(50-100 \mu \mathrm{m})\end{array}$ & 38.4 & 21.8 & $-0.43(0.27)$ & 0.0 & 0.0 & $-1.00(0.00)^{* * *}$ & * 61.1 & 0.0 & $-0.95(0.05)^{* * *}$ & 11.1 & 3.2 & $-0.42(0.19)$ \\
\hline $\begin{array}{l}\text { Coscinodiscus } \\
(100-150 \mu \mathrm{m})\end{array}$ & 10.0 & 16.0 & $-0.13(0.44)$ & 0.5 & 0.5 & $0.58(0.05)^{* *}$ & 9.3 & 35.9 & $0.25(0.11)$ & 0.1 & 0.0 & $-0.10(0.45)$ \\
\hline $\begin{array}{l}\text { Ditylum } \\
(100-150 \mu \mathrm{m})\end{array}$ & 0.0 & 0.0 & $-0.55(0.45)$ & 0.0 & 0.0 & $-0.06(0.48)$ & 0.7 & 0.0 & $-0.85(0.15)^{* *}$ & 0.0 & 0.0 & $-0.15(0.43)$ \\
\hline $\begin{array}{l}\text { Thalassiosira } \\
(25-50 \mu \mathrm{m})\end{array}$ & 0.0 & 0.1 & $0.36(0.07)^{* *}$ & 0.4 & 0.5 & $0.36(0.06)^{*}$ & 6.0 & 11.6 & $-0.49(0.27)$ & 4.8 & 3.5 & $-0.02(0.08)$ \\
\hline $\begin{array}{l}\text { Skeletonema } \\
(5-8 \mu \mathrm{m})\end{array}$ & & & & 67.0 & 97.0 & $0.25(0.12)$ & & & & & & \\
\hline Dinoflagellates & & & & & & & & & & & & \\
\hline $\begin{array}{l}\text { Protoperidinium } \\
(30-40 \mu \mathrm{m})\end{array}$ & 0.3 & 0.9 & $0.36(0.07)^{* *}$ & & & & 4.6 & 10.9 & $-0.45(0.28)$ & 0.5 & 0.1 & $-0.60(0.29)$ \\
\hline $\begin{array}{l}\text { Alexandrium } \\
(15-25 \mu \mathrm{m})\end{array}$ & 0.2 & 0.0 & $-0.58(0.42)$ & & & & 1.1 & 5.3 & $-0.19(0.40)$ & 1.1 & 0.7 & $-0.09(0.09)$ \\
\hline Flagellates & & & & & & & & & & & & \\
\hline $\begin{array}{l}\text { Autotrophic flage } \\
(15-20 \mu \mathrm{m})\end{array}$ & yellates & & & 25.9 & 0.0 & $-1.0(0.0)^{* * *}$ & & & & 65.1 & 81.6 & $0.30(0.07)^{*}$ \\
\hline
\end{tabular}

(Fig. 5). In February, while the abundance distribution of microplanktonic prey available was not significantly different from microplanktonic prey consumed, the cells actually ingested were sufficiently large that Acartia consumed a disproportionate amount (>90\% of total diet) of aloricate ciliate and dinoflagellate biomass. In April, despite a very large concentration of Skeletonema diatoms, Acartia diets were dominated by heterotrophic nanoflagellates (10 to $15 \mu \mathrm{m})$, the only instance in any experiment when individual, non- chain-forming nanoplankton cells were significantly consumed. Acartia did show selection for individual diatom cells in May; however, they also consumed very large loricate ciliates (mostly Eutintinnus) out of proportion to their availability, such that Acartia diet was strongly dominated by loricate ciliate biomass (Fig. 7).

While the prey distributions in Acartia diet were substantially different from the available prey distributions in San Pablo Bay, Acartia did not demonstrate strong preferences for any particular category of prey 
consumed. Fig. 8 shows the clearance rates and electivity indices for the major prey ingested over the experimental period. No prey category showed a significantly positive electivity in any experiment (all $\mathrm{p}>$ 0.05). However, in April electivity for diatoms $>15 \mu \mathrm{m}$ was significantly negative $(p=0.010)$, and electivity for aloricate ciliates was significantly negative $(p=0.026)$ in May, indicating avoidance of these prey in such experiments.

Preference for individual prey taxa. When each prey type was considered individually, the pattern of electivity by Acartia in San Pablo Bay suggests that, while no major prey category was preferred in aggregate, certain genera of prey were more often consumed out of proportion to their availability than others (Table 2). In all 3 feeding experiments between February and May, covering a wide range of prey abundance and taxonomic composition, Acartia always showed a preference for large individuals $(>30 \mu \mathrm{m})$ of the autotrophic ciliate Mesodinium. In February, this group was the only one for which a significantly positive mean electivity was observed. Even during April and May, when diatoms were the most abundant cells present by 2 to 4 times, Acartia rarely preferred diatoms. In contrast, mean electivity indices in April and May were positive for the aloricate ciliates Mesodinium and Strombidium $>25 \mu \mathrm{m}$ in size (Table 2).

Ingestion rates. Ingestion rates of the major prey categories by Acartia in San Pablo Bay were significantly different from each other in April $(p=0.026)$, but differences were non-significant in February and May $(p>0.05)$. As observed in South Bay, mean biomass ingestion rates of Acartia in San Pablo Bay in February were all low, ranging between 0.02 and $0.90 \mathrm{ngC}$ copepod $^{-1} \mathrm{~h}^{-1}$ (Fig. 8). However, when Skeletonema diatoms were blooming in April, Acartia did not consume nanoplanktonic diatoms but instead showed the highest ingestion rates on heterotrophic nanoplankton and loricate ciliates (120 and $20.0 \mathrm{ng} \mathrm{C}$ copepod $^{-1} \mathrm{~h}^{-1}$, respectively). In May, despite the fact that biomass of prey $>15 \mu \mathrm{m}$ remained relatively high, mean ingestion rates declined overall, but were still highest for loricate ciliates (3.3 $\mathrm{ng} \mathrm{C}$ copepod $^{-1} \mathrm{~h}^{-1}$ ) (Fig. 8).

\section{DISCUSSION}

Our major objective in this study was to examine the feeding dynamics of Acartia in San Francisco Bay over a wide range of prey conditions. From February to May 2000 , the abundance and taxonomic composition of the $<200 \mu \mathrm{m}$ planktonic prey assemblage varied considerably both within and between South Bay and San Pablo Bay. Our results suggest that Acartia modified its diet and ingestion rates in response to differences

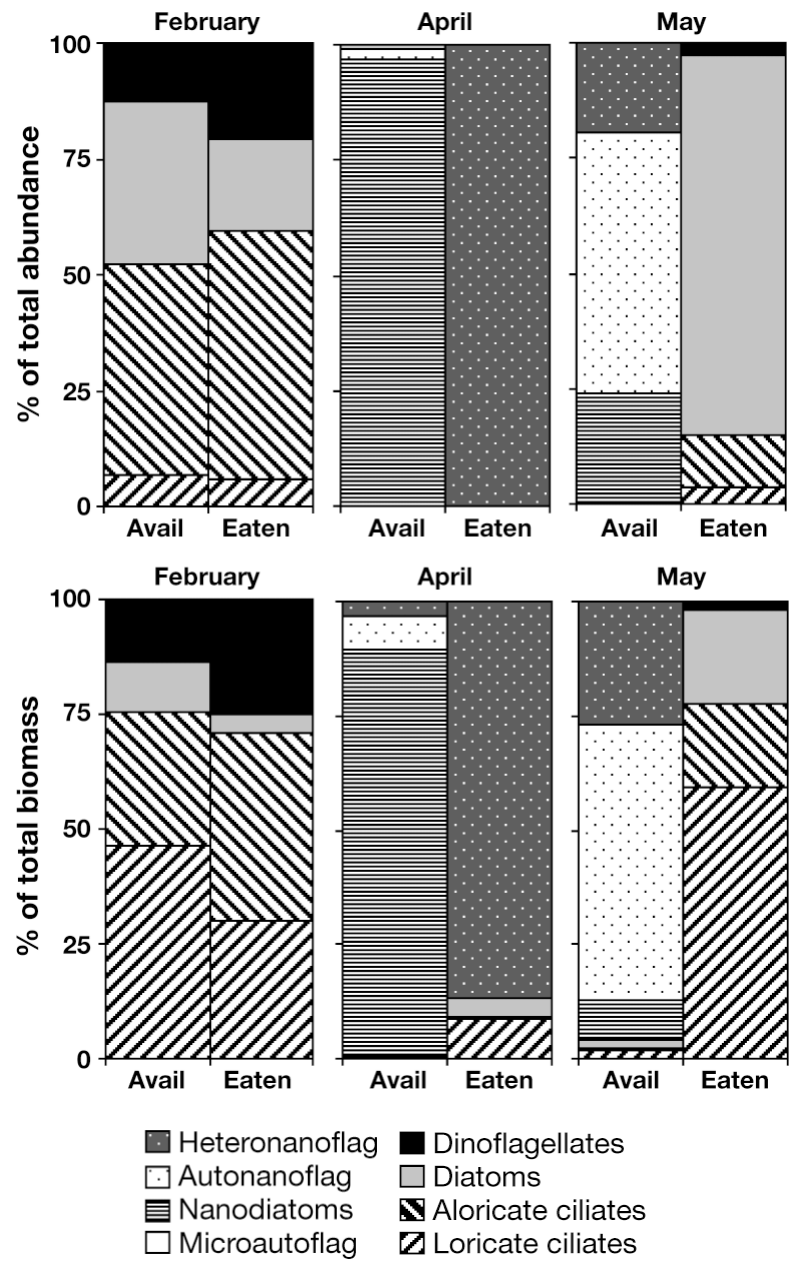

Fig. 7. Relative abundance and biomass of prey categories available vs eaten by Acartia spp. during $12 \mathrm{~h}$ incubations with unfiltered seawater from San Pablo Bay between February and May 2000. Definition of prey categories as in Fig. 3. Avail $=\%$ of total prey biomass available during incubation Eaten $=\%$ of total prey biomass consumed during incubation

in the overall quantity and quality of prey available to them.

\section{Acartia diet composition and feeding selectivity}

In both South Bay and San Pablo Bay Acartia were omnivorous, consuming a diverse diet that included both autotrophic and heterotrophic prey from a range of taxonomic groups (i.e. ciliates, diatoms, dinoflagellates and other flagellates). Other field studies of Acartia diet composition have shown similar dietary diversity. Kleppel (1992) found A. tonsa in coastal waters off southern California to have diets most often dominated by ciliate and dinoflagellate biomass $(58 \%)$, followed by nanoplankton ( $33 \%$ ) and diatoms ( $4 \%$ ). In a similar 
field study conducted in Florida Bay, A. tonsa diets were also comprised of a range of prey, including diatoms, dinoflagellates, heterotrophic protists and nanoplankton, and were rarely dominated by any single prey category (Kleppel \& Hazzard 2000). Indeed, dietary diversity may be the rule rather than the exception for calanoid copepods, since mixed diets have been observed in the field for several other common genera, including Centropages, Undinula, Temora, Eucalanus, and Calanus (Kleppel et al. 1996, Verity \& Paffenhofer 1996, Nejstgaard et al. 2001a). Consuming a combination of prey types likely allows copepods to adjust their diet under variable conditions of food availability, and may increase their chances for obtaining a nutritionally complete ration (Kleppel 1993).

Our results from San Francisco Bay show not only that Acartia were omnivorous and consumed a wide range of prey types, but that they were highly selective for the prey they did ingest. Many factors may affect the preferences of calanoid copepods feeding on natural prey assemblages, including cell size, prey density, nutritional quality and behavior. A comparison of

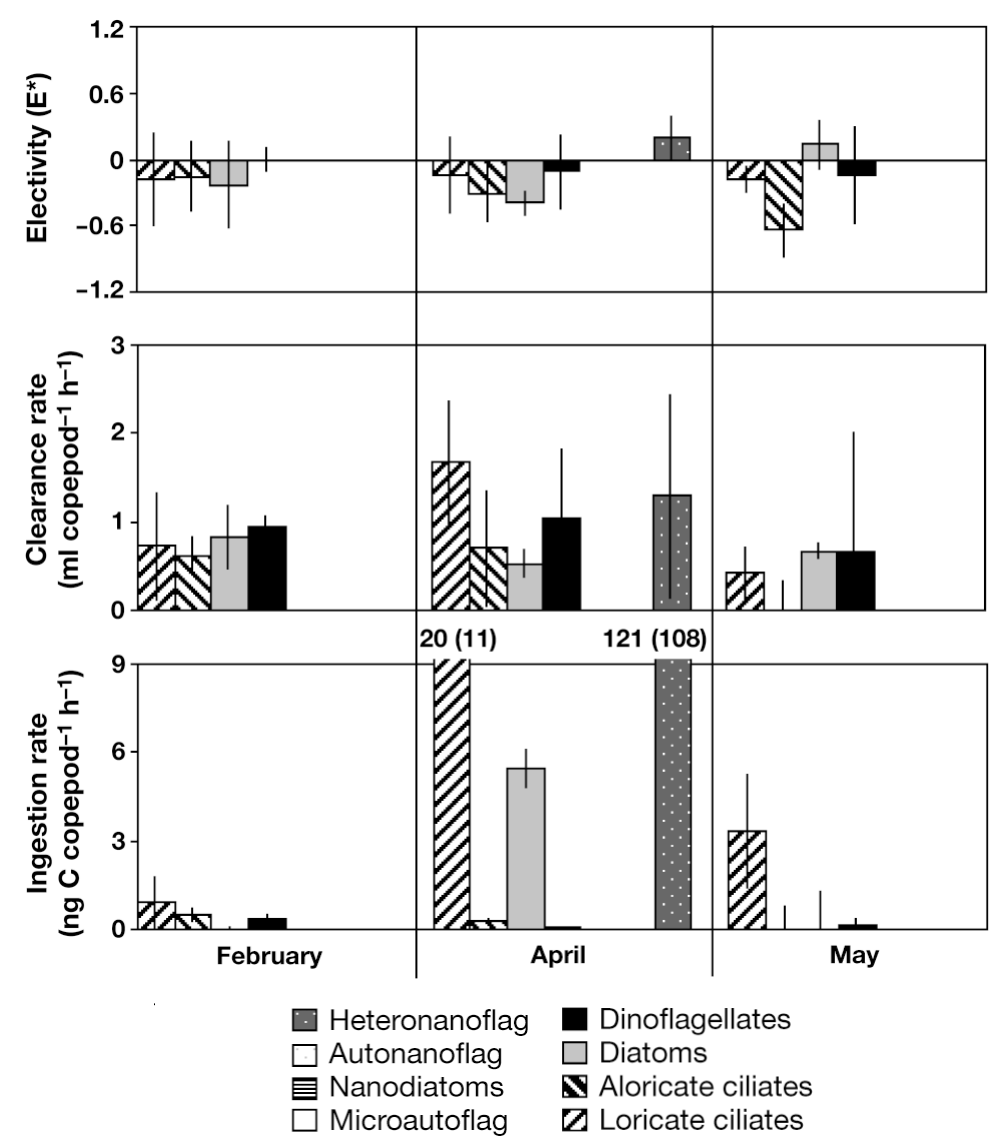

Fig. 8. Acartia spp. Electivity, clearance rates and ingestion rates during $12 \mathrm{~h}$ incubations with unfiltered seawater from San Pablo Bay between February and May 2000. Definition of prey categories as in Fig. 3. Error bars = $1 \mathrm{SE}$ feeding rates and selectivity both within and between South Bay and San Pablo Bay demonstrated that Acartia may have modified their diet according to the balance of these factors in each location.

\section{Size}

Comparisons of prey distributions from copepod diets and in the available feeding medium showed that Acartia in both South Bay and San Pablo Bay primarily preferred prey cells $>15 \mu \mathrm{m}$ in size, and never significantly consumed cells $<10 \mu \mathrm{m}$, even though cells $<15 \mu \mathrm{m}$ were by far the most abundant. Moreover, the pattern of electivity indices showed Acartia frequently targeted prey $>25 \mu \mathrm{m}$ in size compared to smaller individuals regardless of prey type, even under dramatically different conditions of overall prey abundance.

These results are supported by laboratory studies which have previously demonstrated that Acartia will selectively consume larger cells when presented with either beads or phytoplankton cells over a wide range of sizes (Wilson 1973, Nival \& Nival 1976). In the field, size-selective feeding by Acartia has also been observed. Tiselius (1989) found A. clausi from Scandinavian coastal waters to increase clearance of ciliates as cell size increased, with a plateau at $>25 \mu \mathrm{m}$ equivalent spherical diameter. In addition, A. tonsa selected for medium or large particles in a French brackish lagoon, regardless of the shape of the particle-size spectrum (Gaudy et al. 1996). Similarly, A. tonsa and A. clausi both demonstrated selective feeding on large cells from natural suspensions of Chesapeake Bay plankton over a wide range of particle distributions (Richman et al. 1977).

Prey selection based on size has also been shown to be important for other calanoid copepods in feeding incubations using natural plankton assemblages, including Centropages brachiatus (Cowles 1979), Calanus finmarchicus (Ohman \& Runge 1994), Eucalanus pileatus (Verity \& Paffenhofer 1996), Temora stylifora (Kleppel et al. 1996), Eurytemora affinis (Merrell \& Stoecker 1998), Calanus glacialis, C. hyperboreus (Levinson et al. 2000), and Temora longicornis (Vincent \& Hartmann 2001).

Increased selectivity for large prey by suspension-feeding copepods is likely due to their easier detection and capture relative to smaller cells (Jonsson \& Tiselius 1990), especially in very particle-rich environments (Stoecker \& Egloff 1987) such as San Francisco Bay. However, size alone cannot account for all of the prey selectivity by Acartia observed in San Francisco Bay. 
Table 2. Individual taxa representing $>2 \%$ of total prey consumed by Acartia spp. during $12 \mathrm{~h}$ incubations with unfiltered seawater from San Pablo Bay between February and May 2000. Avail $=\%$ of total prey biomass available during incubation; Eaten $=\%$ of total prey biomass consumed during incubation; $\mathrm{E}^{*}$ : mean $( \pm 1 \mathrm{SE})$ electivity index for that prey taxon during incubation. Positive $\mathrm{E}^{*}$ : preference, negative $\mathrm{E}^{*}$ : avoidance. Bold indicates $\mathrm{E}^{*}$ significantly different from zero, with ${ }^{*} \mathrm{p}<0.05,{ }^{* *} \mathrm{p}<0.025$, ${ }^{* * *} p<0.01$

\begin{tabular}{|c|c|c|c|c|c|c|c|c|c|}
\hline \multirow{2}{*}{ Prey type } & \multicolumn{3}{|c|}{ February } & \multicolumn{3}{|c|}{$\longrightarrow$ April } & \multirow[b]{2}{*}{ Avail } & \multirow{2}{*}{$\overline{\text { Eaten }}$} & \multirow[b]{2}{*}{$\mathrm{E}^{*}$} \\
\hline & Avail & Eaten & $\mathrm{E}^{*}$ & Avail & Eaten & $E^{*}$ & & & \\
\hline \multicolumn{10}{|l|}{ Loricate ciliates } \\
\hline Codonellopsis (80-100 ㅆm) & 3.2 & 0.0 & $-0.06(0.47)$ & 3.2 & 0.1 & $-0.41(0.31)$ & 28.8 & 39.1 & $-0.20(0.08)$ \\
\hline Eutintinnus $(250-300 \mu \mathrm{m})$ & 8.0 & 0.0 & $-0.48(0.52)$ & 2.8 & 3.3 & $0.10(0.06)$ & 1.4 & 1.7 & $-0.13(0.44)$ \\
\hline Unknown tintinnid $(80-100 \mu \mathrm{m})$ & 3.0 & 1.2 & $-0.55(0.45)$ & 0.0 & 0.0 & $-0.17(0.41)$ & 0.4 & 0.5 & $-0.58(0.42)$ \\
\hline \multicolumn{10}{|l|}{ Aloricate ciliates } \\
\hline Strombidium (15-25 ㅆm) & 0.8 & 1.8 & $0.10(0.22)$ & 0.0 & 0.0 & $0.26(0.02)^{* * *}$ & 0.1 & 0.5 & $0.22(0.07)^{*}$ \\
\hline Strombidium $(25-50 \mu \mathrm{m})$ & 10.7 & 3.1 & $-0.35(0.36)$ & 0.1 & 0.1 & $0.11(0.09)$ & 1.0 & 3.5 & $0.29(0.02)^{* * *}$ \\
\hline Halteria $(10-20 \mu \mathrm{m})$ & 0.4 & 0.0 & $-0.09(0.46)$ & 0.0 & 0.0 & $-0.17(0.41)$ & 0.4 & 0.7 & $-0.05(0.08)$ \\
\hline Mesodinium $(20-30 \mu \mathrm{m})$ & 9.5 & 3.1 & $-0.71(0.29)$ & 0.0 & 0.0 & $-0.66(0.34)$ & 4.8 & 0.0 & $-0.97(0.03)^{* * *}$ \\
\hline Mesodinium (30-40 $\mu \mathrm{m})$ & 7.2 & 31.0 & $0.46(0.06)^{* * *}$ & 0.0 & 0.0 & $0.26(0.02)^{* * *}$ & 0.8 & 2.8 & $0.29(0.02)^{* * *}$ \\
\hline \multicolumn{10}{|l|}{ Diatoms } \\
\hline Coscinodiscus $(30-50 \mu \mathrm{m})$ & 1.8 & 1.2 & $-0.45(0.29)$ & 0.5 & 0.0 & $-0.78(0.22)^{*}$ & 6.9 & 10.9 & $-0.13(0.07)$ \\
\hline Coscinodiscus $(50-100 \mu \mathrm{m})$ & 6.5 & 2.4 & $-0.66(0.34)$ & 3.0 & 1.8 & $-0.25(0.13)$ & 21.4 & 6.1 & $-0.70(0.30)$ \\
\hline Coscinodiscus $(100-150 \mu \mathrm{m})$ & 1.8 & 0.0 & $0.01(0.50)$ & 1.8 & 2.2 & $0.10(0.03)^{*}$ & 16.5 & 0.0 & $-0.69(0.31)$ \\
\hline Ditylum & 0.2 & 0.0 & $-0.55(0.45)$ & & & & & & \\
\hline Thalassiosira $(25-50 \mu \mathrm{m})$ & 0.1 & 0.0 & $-0.51(0.49)$ & 0.0 & 0.0 & $-0.15(0.42)$ & 1.5 & 3.8 & $0.07(0.15)$ \\
\hline Guinardia $(40-60 \mu \mathrm{m})$ & & & & & & & 0.0 & 0.0 & $-0.01(0.11)$ \\
\hline Navicula $(80-100 \mu \mathrm{m})$ & 0.1 & 0.2 & $-0.29(0.32)$ & 0.0 & 0.0 & $-0.19(0.30)$ & 0.0 & 0.0 & $-0.33(0.34)$ \\
\hline Rhizoselenia (150-175 بm) & 0.3 & 0.2 & $-0.62(0.38)$ & 0.0 & 0.0 & $-0.79(0.21)^{*}$ & 0.0 & 0.0 & $0.29(0.02)^{* * *}$ \\
\hline Protoperidinium $(30-40 \mu \mathrm{m})$ & 0.5 & 0.0 & $-0.85(0.15)$ & 0.1 & 0.0 & $-0.23(0.20)$ & 0.4 & 0.6 & $-0.15(0.43)$ \\
\hline Ceratium $(100-150 \mu \mathrm{m})$ & 9.9 & 16.7 & $-0.13(0.20)$ & & & & & & \\
\hline \multicolumn{10}{|l|}{ Flagellates } \\
\hline $\begin{array}{l}\text { Heterotrophic flagellates } \\
(10-15 \mu \mathrm{m})\end{array}$ & & & & 83.2 & 86.9 & $-0.10(0.31)$ & & & \\
\hline
\end{tabular}

Trophic status and nutritional quality

While Acartia diets in both South Bay and San Pablo Bay were diverse and comprised of prey $>10$ to $15 \mu \mathrm{m}$ in size, the amount of autotrophic vs heterotrophic prey ingested differed between the 2 locations, most likely in response to differences in the suite of available food resources. South Bay provided higher abundance and biomass of microplankton (15 to $200 \mu \mathrm{m}$ ) prey than San Pablo Bay. In addition, South Bay exhibited a more substantial chl a increase in early April, likely due to blooms of 15 to $20 \mu \mathrm{m}$ autotrophic flagellates, as well as increased abundance of the autotrophic ciliate Mesodinium, in addition to the bloom of Skeletonema. Similarly, a greater proportion of Acartia diets in South Bay was comprised of autotrophic prey than in San Pablo Bay. In all experiments in South Bay at least $50 \%$ of the prey biomass consumed by Acartia was autotrophic (including diatoms and Mesodinium), and this category exceeded $80 \%$ of their diet in March and May.

In San Pablo Bay Skeletonema diatoms also bloomed in April; however, the microplankton prey assemblage was characterized by fewer, but relatively larger, diatoms (Coscinodiscus) and loricate ciliates (Codonellopsis and Eutintinnus) than South Bay. During April and May in San Pablo Bay, Acartia diets were strongly dominated by heterotrophic prey $>10 \mu \mathrm{m}$ in size, with heterotrophic ciliates and 10 to $15 \mu \mathrm{m}$ heterotrophic flagellates always representing $>60 \%$ of the total biomass consumed, and no significant consumption of Skeletonema. Possibly the Skeletonema diatoms in San Pablo Bay were of lesser quality than those in South Bay, perhaps due to senescence or having been advected into San Pablo Bay from points further upstream (Lehman 1996).

The greater proportion of autotrophic prey consumed in South Bay relative to San Pablo Bay is likely due primarily to higher abundance of large $(>15 \mu \mathrm{m})$ diatoms and autotrophic flagellates. But even under bloom conditions, Acartia continued to consume heterotrophic ciliate and dinoflagellate biomass out of proportion to their availability in both bays. This suggests that other mechanisms besides size and availability were also driving Acartia prey selectivity.

One explanation for Acartia preferences for ciliates in San Francisco Bay is their potential nutritional benefit as part of a diverse diet (Kleppel 1993). Several lab- 
oratory studies have demonstrated that $A$. tonsa may select higher quality prey (e.g. exponentially growing or nutritionally rich vs senescent or nutritionally poor) using sensory perception (Libourel Houde \& Roman 1987, Cowles et al. 1988). Ciliates typically have lower carbon:nitrogen ratios than algae, making them a more efficient source of proteins and amino acids (Kiørboe et al. 1985, Stoecker \& Capuzzo 1990). In addition, through their own grazing, as well as de novo production, protozoans may provide enhanced levels of important organic components that copepods cannot synthesize themselves, including polyunsaturated fatty acids, highly unsaturated fatty acids (HUFA) and sterols (Sanders \& Wickham 1993). Klein Breteler et al. (1999) showed that protozoans not only 'repackaged' organic material by assimilating bacterial or algal HUFA from their own diets, but also enhanced copepod growth when these protozoans were incorporated into the copepod diet.

Similarly, laboratory studies have shown copepod egg production and survival to improve when protozoans were a part of the diet (Berk et al. 1977, Stoecker \& Egloff 1987, Bonnet \& Carlotti 2001). Several reports have also implicated diatoms as negatively affecting copepod fecundity and hatching success, especially during diatom blooms (Ban et al. 1997), but this effect was reduced when protists were included in the diet (Poulet et al. 1994, Ianora et al. 1995, Miralto et al. 1999).

In the field, the effect of protozoans on copepod egg production also appears to be beneficial. For instance, egg production of Acartia tonsa in Chesapeake Bay was found to be strongly correlated with temperature and protozoan biomass, but not with phytoplankton biomass, production or ingestion (White \& Roman 1992). In addition, the combination of dinoflagellate and ciliate biomass in the diet explained $71 \%$ of the variability in egg production of several calanoid copepod species, including $A$. tonsa, in a range of estuarine and coastal waters (Kleppel et al. 1991). Egg production of Calanus finmarchicus in the Gulf of St. Lawrence was also uncorrelated with any measure of phytoplankton biomass or production, but C. finmarchicus produced consistently high numbers of eggs when heterotrophic microplankton were consumed (Ohman \& Runge 1994). Lonsdale et al. (1996) showed Acartia spp. egg production to be positively correlated with the net growth rates of ciliates in 2 Long Island bays.

However, in cold, temperate waters where ciliates were a more variable component of total microplankton abundance, ciliate biomass did not impact Acartia clausi egg production (Tiselius 1989). The relationship between copepod feeding and egg production is complex, and the more predictive factors may be individual nutrients from among prey consumed rather than the prey organisms themselves (Kleppel et al. 1998). However, both the laboratory and field evidence is compelling to support the idea that protozoans provide an equal, and probably superior, source of nutrition for copepods as phytoplankton.

\section{Behavior}

In both South Bay and San Pablo Bay, motile prey (ciliates and flagellates) made up at least $50 \%$ of the Acartia diet, except during March in South Bay, when Acartia nearly exclusively consumed the chain-forming diatom Skeletonema. Ciliates, dinoflagellates and heterotrophic nanoflagellates were particularly dominant components of Acartia diets in San Pablo Bay, where they were always $>80 \%$ of the total biomass consumed. While size and nutritional quality may have been important in determining Acartia preferences, the behavior of both the prey and the copepods could also have resulted in motile prey being most often ingested.

Acartia tonsa readily exhibits 2 types of feeding modes: raptorial or ambush behavior when detecting motile prey, and suspension-feeding behavior when encountering non-motile prey (Jonsson \& Tiselius 1990). A. tonsa has been observed in the laboratory to switch between these 2 feeding strategies in order to maximize energy intake (Kiørboe et al. 1996). This was corroborated by Jakobsen (2001), who found that $A$. tonsa was able to capture ciliates that had strong escape responses, whereas copepods capable of only suspension feeding could not. Kiørboe et al. (1996) also demonstrated that when presented with a mixture of non-motile diatoms and motile ciliates, $A$. tonsa maintained relatively constant clearance rates on ciliates regardless of diatom abundance, but decreasing clearance of diatoms as ciliate concentration increased. In addition they found that turbulence favored the selection of ciliates vs diatoms as prey. Mobility on the part of both copepods and their prey, and turbulence in the environment, would thus serve to increase the encounter rates of copepods and ciliates and/or flagellates. This could help to explain why we found motile prey (loricate ciliates and nanoflagellates) to be strongly selected for by Acartia in San Pablo Bay, where turbulent mixing is typically higher than South Bay, especially during high river flow in the winter and spring (Cloern et al. 1985).

Differences in motility cannot, however, account for the apparent preference of Acartia for heterotrophic flagellates over autotrophic flagellates in San Pablo Bay. In this case it is possible that trophic dynamics within the incubation bottles themselves could have 
contributed to the lack of significant reduction in autotrophic nanoflagellate and nanodiatom abundance. The unfiltered natural plankton assemblage used as the feeding medium for Acartia necessarily included a number of trophic levels below the added copepod grazers. The heterotrophic microplankton, primarily the ciliates and heterotrophic dinoflagellates, are known to be significant grazers of small phytoplankton (see 'Introduction'). Thus the feeding pressure exerted on the ciliates by Acartia could have released the autotrophic nanoflagellates from microplankton grazing, resulting in a lack of appreciable reduction in autotrophic nanoflagellate abundance between the control and treatment incubation bottles in our experiments. Such indirect effects of mesozooplankton grazing on nanoplankton in incubation studies have been reported by others (Miller et al. 1995, Nejstgaard et al. 2001b), and are likely common in marine environments (Calbet \& Landry 1999), especially in San Francisco Bay, where there may be several trophic levels between primary producers and copepods.

Finally, the pattern of Acartia prey selectivity observed in San Francisco Bay, with greater selectivity for individual prey genera during periods of high food abundance and lesser selectivity during periods of low food abundance, is consistent with the predictions of optimal foraging theory (reviewed in Pyke 1984). In particular, Lehman (1976) developed a model for suspension-feeding zooplankton that predicted selection based on food quality rather than strictly by the physical constraints of their filtering mechanism, and that selection for preferred foods would be stronger when in high abundance and weaker when food was in low abundance. Laboratory results with Eudiaptomus spp. feeding upon mixtures of living algae of varying quality, polystyrene spheres and dead algae supported Lehman's (1976) model, and further showed that in the laboratory copepods may discern prey based on a combination of size and quality in order to maximize energy input (DeMott 1989). Our results from experiments with Acartia feeding upon the natural prey assemblage in San Francisco Bay provide further field evidence to support the model of optimal foraging in suspension-feeding zooplankton.

\section{Ingestion rates}

Despite exhibiting strong preferences for particular prey, Acartia in San Francisco Bay showed relatively low ingestion rates on the major categories of prey, typically falling within a relatively narrow range, between 0 and $6 \mathrm{ng} \mathrm{C}$ copepod $^{-1} \mathrm{~h}^{-1}$. However, ingestion rates did increase during periods of maximal prey abun- dance. In South Bay, ingestion of nanoplanktonic diatoms exceeded $200 \mathrm{ng} \mathrm{C}$ copepod $^{-1} \mathrm{~h}^{-1}$ during March, and ingestion of autotrophic flagellates reached 90 ng C copepod ${ }^{-1} \mathrm{~h}^{-1}$ in May. Similarly, in San Pablo Bay, ingestion of heterotrophic nanoflagellates rose to $120 \mathrm{ng} \mathrm{C}$ copepod $^{-1} \mathrm{~h}^{-1}$ during April. Assuming $2.86 \mu \mathrm{g}$ C ind..$^{-1}$ for adult female A. clausi in San Francisco Bay (Hutchinson 1981), the total carbon ingested during non-peak periods averaged only $6.3 \%$ of body $\mathrm{C} \mathrm{d}^{-1}$ in South Bay, and only $2.2 \%$ of body $\mathrm{C} \mathrm{d}^{-1}$ in San Pablo Bay. In contrast, ingestion of nanoplanktonic diatoms alone was sufficient to provide $188 \%$ of body $\mathrm{C} \mathrm{d}^{-1}$ during March in South Bay, and autotrophic flagellates provided $76 \%$ of body $\mathrm{C} \mathrm{d}^{-1}$ during May. In San Pablo Bay, ingestion of heterotrophic flagellates accounted for $101 \%$ of body $\mathrm{C} \mathrm{d}^{-1}$ in April.

Comparable field studies of Acartia feeding in estuaries are few; however, our ingestion rate results are generally consistent with those reported in the literature. Biomass ingestion rates of protozoans by $A$. tonsa in a Louisiana estuary averaged $\sim 87 \mathrm{ng} \mathrm{C}$ copepod $^{-1}$ $\mathrm{h}^{-1}$ in August, when $91 \%$ of available prey carbon was contained in phytoplankton $<5 \mu \mathrm{m}$ in size, but was especially low $\left(\sim 4 \mathrm{ng} \mathrm{C}\right.$ copepod $\left.^{-1} \mathrm{~h}^{-1}\right)$ in January, when $95 \%$ of phytoplankton was in the $>5 \mu \mathrm{m}$ size fraction (Gifford \& Dagg 1991). In addition, ingestion rates of ciliate carbon by Acartia spp. (A. hudsonica and $A$. tonsa) in 2 Long Island bays ranged between 0 and $69 \mathrm{ngC}$ copepod $^{-1} \mathrm{~h}^{-1}$, and was most often $<10 \mathrm{ng} \mathrm{C}$ copepod ${ }^{-1} \mathrm{~h}^{-1}$ (Lonsdale et al. 1996). In contrast, A. tonsa in Florida Bay had ingestion rates that were often near maximal temperature- and fooddependent levels, averaging $\sim 200 \mathrm{ng} \mathrm{C}$ copepod $^{-1} \mathrm{~h}^{-1}$ through much of the year (Kleppel \& Hazzard 2000).

Kleppel (1992) simultaneously measured ingestion rates and egg production of $A$. tonsa in Los Angeles Harbor, and found that egg production required $16.5 \%$ of body $\mathrm{C} \mathrm{d}^{-1}$ at comparable temperatures as our experiments. If we apply these rates in San Francisco Bay, Acartia did not ingest sufficient prey biomass of any type to meet reproductive requirements in 4 of 7 experiments. However, when chlorophyll levels were at their maximum Acartia could fulfill its energy requirements by consuming small diatoms and autotrophic flagellates in South Bay, and small heterotrophic flagellates and ciliates in San Pablo Bay.

\section{Implications of Acartia feeding for the planktonic food web}

The results of our feeding experiments demonstrate that when chl a levels and overall prey abundances were low in San Francisco Bay, $>50 \%$ of the biomass consumed by Acartia came from ciliates. Since blooms 
in South Bay typically occur only briefly in the spring and may no longer occur to any significant or predictable degree in San Pablo Bay (although they may be rebounding, see 'Introduction'), these protozoans may serve as a crucial dietary supplement to phytoplankton biomass for much of the year throughout San Francisco Bay.

Considerable evidence from both laboratory experiments and field observations demonstrates that protozoans, in particular ciliates and heterotrophic flagellates, are the primary herbivores and bacterivores in open ocean and coastal marine planktonic food webs (reviewed in Sherr \& Sherr 1994, Strom 2000). In addition, protozoan grazing has been shown to be especially important in a range of estuaries, on both phytoplankton (e.g. Gifford 1988, Gallegos 1989, McManus \& Ederington-Cantrell 1992, Dagg 1995, Froneman \& McQuaid 1997, Ruiz et al. 1998, Sautour et al. 2000) and bacterioplankton (e.g. Sherr \& Sherr 1985, B. R. Sherr et al. 1986). Based on these studies, the heterotrophic protists consumed by Acartia in San Francisco Bay could be the link to bacterial and algal production that would otherwise be unavailable to the copepods directly.

In South Bay, microzooplankton may indeed be important grazers of both small phytoplankton and cyanobacteria. Murrell \& Hollibaugh (1998) conducted dilution experiments during spring and summer in South Bay and found that microzooplankton grazing rates were significant in 5 out of 7 experiments, averaging $0.41 \mathrm{~d}^{-1}$ for phytoplankton (measured as chlorophyll) and $1.84 \mathrm{~d}^{-1}$ for cyanobacteria. Moreover, in all but 1 of the 5 significant experiments, microzooplankton grazing was sufficient to balance both phytoplankton and cyanobacterial growth. Interestingly, the only 2 instances when microzooplankton grazing rates were not significant were during the spring phytoplankton bloom.

When these data are considered in conjunction with our results of Acartia feeding, a potential scenario for the trophic dynamics of the lower food web in South Bay begins to emerge. During non-bloom periods the microzooplankton (here shown to be mostly heterotrophic ciliates and nanoflagellates) comprise $\sim 55 \%$ of Acartia diet, and may be the primary planktonic grazers of phytoplankton. This would translate into a system with potentially 3 trophic levels from primary producers to copepods, and could mean lower efficiency of energy transfer than if copepods were exclusively grazing phytoplankton. However, some of the energy loss could be offset by enhanced nutritional quality of protozoans. Conversely, during the spring bloom, growth of diatoms, particularly chain-forming Skeletonema, may exceed protozoan grazing, and they may be directly consumed by Acartia.
Although it was not measured directly in this study, higher energy efficiency at the base of the planktonic food web in South Bay during bloom periods may result in higher copepod production relative to non-bloom conditions. This may, in turn, result in enhanced fish production if fish spawning is coincident with the bloom. Indeed, Acartia clausi abundance was shown to increase in spring 1980 coincident with the phytoplankton bloom in South Bay (Ambler et al. 1985), and more recent (1997 to 1999) investigations of copepod dynamics in San Francisco Bay show a spring copepod population increase (S. M. Bollens unpubl. data). In addition, Pacific herring, one of the numerically dominant planktivorous fish species in San Francisco Bay, was also most abundant during the spring and summer of 1980 (Armor \& Herrgesell 1985). This lends support to the idea that relatively short-lived but significant bloom periods in South Bay may be important times of increased productivity throughout the planktonic food web.

In San Pablo Bay the linkages within the lower food web may be quite different from South Bay. In the same study of microzooplankton grazing, Murrell \& Hollibaugh (1998) found both herbivory and bactivory by phagotrophic protists $<200 \mu \mathrm{m}$ to be unexpectedly low in northern San Francisco Bay (including San Pablo Bay). Of 14 dilution experiments measuring grazing upon the phytoplankton community, only 3 returned statistically significant results. Similarly, only 2 of 6 dilution experiments measuring growth and grazing on the bacterioplankton community produced significant results. But of the 5 experiments where results were significant, microzooplankton grazing was higher than phytoplankton and/or bacterial growth. Nonetheless, based on the low number of experiments that showed statistically significant grazing rates, the authors concluded that microzooplankton have only a weak grazing impact in northern San Francisco Bay, and proposed instead that benthic suspension feeders may exert a stronger control on phytoplankton and bacterial populations.

Our results show that Acartia in San Pablo Bay consumed heterotrophic ciliate and flagellate biomass to a significantly higher degree than diatoms or any other autotrophic prey, even during a bloom of Skeletonema, and that in April these prey provided $>100 \%$ of Acartia body carbon per day. If grazing on either phytoplankton or bacterioplankton by protozoans is not significant in San Pablo Bay, then it is difficult to explain the order of magnitude increase in ciliate biomass that we observed between February and April, when chl a levels peaked. Nor can we explain the preferential consumption of ciliates and heterotrophic flagellates by Acartia. However, closer examination of the dilution experiment technique may help to reconcile these apparently conflicting results. 
Murrell \& Hollibaugh (1998) pointed out that their conclusion of low microzooplankton grazing in northern San Francisco Bay was complicated by the possibility that some of the dilution method assumptions may not hold in this environment (e.g. differences in light levels between dilution treatments, various predator-prey interactions). Dolan et al. (2000) examined the effects of dilution on a range of microzooplankton groups from the Rhode River estuary, including rotifers, tintinnid (loricate) ciliates, heterotrophic aloricate ciliates, and autotrophic aloricate ciliates (Mesodinium rubrum). They found that, contrary to the assumptions of the dilution method, not all microzooplankton grazers were reduced in abundance with increasing dilution and that loricate ciliates actually had higher growth rates in the more dilute treatments than the undiluted treatments. Based on these results Dolan et al. (2000) suggest that there could be uncertainty in measured grazing rates from dilution experiments, and that the grazers in each experiment must be examined in order to determine any artifacts in grazing rate estimates.

Therefore, it is possible that the lack of significant grazing rates observed in San Pablo Bay by Murrell \& Hollibaugh (1998) could be due more to complications from the dilution method than the actual lack of grazing on phytoplankton or bacteria by the microzooplankton. It may also be possible, therefore, that the few experiments where grazing rates were significant, and exceeded phytoplankton and bacterial growth rates, are more reflective of microzooplankton feeding behavior. This is speculative and can only be addressed through further investigations of heterotrophic protist grazing rates and diets in San Francisco Bay. However, it seems clear that in San Pablo Bay protozoans (i.e. ciliates and heterotrophic flagellates) are an important component of the planktonic food web, and that throughout the winter and spring they form the bulk of Acartia diet.

Thus, as in South Bay during non-bloom periods, the dominant planktonic pathway for carbon and energy in the San Pablo Bay is most likely through 3 or more trophic levels from phytoplankton to copepods. Further, when elevations in chl a concentration do occur in San Pablo Bay, copepods continue to consume protozoans, but at higher rates, and therefore likely have higher productivity than during periods of low chlorophyll. While this can only be assessed through direct measurements of copepod productivity (e.g. egg production experiments), spring bloom periods in San Pablo Bay may be windows of opportunity for copepod and fish production, but most likely at a lower magnitude than South Bay due to the additional trophic step.

In summary, Acartia in San Francisco Bay are omnivorous feeders, frequently exhibiting preferences for particular prey types based on a combination of factors including size, nutritional quality and motility, and generally following the predictions of optimal foraging theory. In South Bay diatoms and autotrophic flagellates are often consumed, especially during the spring phytoplankton bloom, while in San Pablo Bay heterotrophic ciliates and flagellates are the dominant prey for Acartia, regardless of phytoplankton abundance. Ingestion rates on prey biomass in both bays are relatively low, but within the range observed in other estuaries, and may not be enough to meet Acartia's dietary requirements except during bloom periods. Thus the spring elevations in phytoplankton biomass could be a crucial time for Acartia production, and perhaps higher trophic levels as well.

Acknowledgements. We gratefully acknowledge the Romberg Tiburon Center for Environmental Studies at San Francisco State University (RTC/SFSU) for the use of small boats for sample collections in San Francisco Bay. Julia Fulmer provided invaluable assistance in the field and laboratory. We thank Mary Silver of the University of California, Santa Cruz, for microscope time and laboratory space for GRB during AY 2000-2001. We especially acknowledge Steve Bollens of RTC/SFSU for his thoughtful advice and support, as well as the comments from 3 anonymous reviewers. This project was supported in part by the National Science Foundation Alan T. Waterman award (OCE-9320572) to D.L.P.

\section{LITERATURE CITED}

Alpine AE, Cloern JE (1992) Trophic interactions and direct physical effects control phytoplankton biomass and production in an estuary. Limnol Oceanogr 37:946-955

Ambler JW, Cloern JE, Hutchinson A (1985) Seasonal cycles of zooplankton from San Francisco Bay. Hydrobiologia 129:177-197

Armor C, Herrgesell PL (1985) Flow-related variation in San Francisco Bay fish communities: 1980-1982. Hydrobiologia 129:211-227

Azam F, Fenchel T, Field JG, Gray JS, Meyer-Reil LA, Thingstad F (1983) The ecological role of water-column microbes in the sea. Mar Ecol Prog Ser 10:257-263

Ban S, Burns C, Castel J, Chaudron Y and 19 others (1997) The paradox of diatom-copepod interactions. Mar Ecol Prog Ser 157:287-293

Bautista B, Harris RP (1992) Copepod gut contents, ingestion rates and grazing impact on phytoplankton in relation to size structure of zooplankton and phytoplankton during a spring bloom. Mar Ecol Prog Ser 82:41-50

Bennett WA, Moyle PB (1996) Where have all the fishes gone? Interactive factors producing fish declines in the Sacramento-San Joaquin Estuary. In: Hollibaugh JT (ed) San Francisco Bay: the ecosystem. Pacific Division of the American Association for the Advancement of Science, San Francisco, p 519-542

Berk SG, Brownlee DC, Heinle DR, Kling HJ, Colwell RR (1977) Ciliates as a food source for marine planktonic copepods. Microbiol Ecol 4:27-40

Bollens SM, Cordell JR, Avent S, Hooff R (2002) Zooplankton invasions: a brief review, plus two case studies from the Northeast Pacific Ocean. Hydrobiologia 480:87-110 
Bonnet D, Carlotti F (2001) Development and egg production in Centropages typicus (Copepoda: Calanoida) fed different food types: a laboratory study. Mar Ecol Prog Ser 224: 133-148

Burkill PH, Mantoura RFC, Llewellyn CA, Owens NJP (1987) Microzooplankton grazing and selectivity of phytoplankton in coastal waters. Mar Biol 93:581-590

Calbet A, Landry MR (1999) Mesozooplankton influences on the microbial food web: direct and indirect trophic interactions in the oligotrophic open ocean. Limnol Oceanogr 44:1370-1380

Chesson J (1983) The estimation and analysis of preference and its relationship to foraging models. Ecology 64: 1297-1304

Cloern JE (1991) Tidal stirring and phytoplankton bloom dynamics in an estuary. J Mar Res 49:203-221

Cloern JE, Cole BE, Wong RLJ, Alpine A (1985) Temporal dynamics of estuarine phytoplankton: a case study of San Francisco Bay. Hydrobiologia 129:153-176

Confer JL, Moore MV (1987) Interpreting selectivity indices calculated from field data or conditions of prey replacement. Can J Fish Aquat Sci 44:1529-1533

Conomos TJ, Smith RE, Gartner JW (1985) Environmental setting of San Francisco Bay. Hydrobiologia 129:1-12

Cowles TJ (1979) The feeding response of copepods from the Peru upwelling system: food size selection. J Mar Res 37 : 601-622

Cowles TJ, Olson RJ, Chisholm SW (1988) Food selection by copepods: discrimination on the basis of food quality. Mar Biol 100:41-49

Crawford DW (1989) Mesodinium rubrum: the phytoplankter that wasn't. Mar Ecol Prog Ser 58:161-174

Dagg MJ (1993) Grazing by the copepod community does not control phytoplankton in the subarctic Pacific Ocean. Prog Oceanogr 32:163-183

Dagg MJ (1995) Ingestion of phytoplankton by the micro- and mesozooplankton communities in a productive subtropical estuary. J Plankton Res 17(4):845-857

Dam HG, Miller CA, Jonasdottir SH (1993) The trophic role of mesozooplankton at $47^{\circ} \mathrm{N}, 20^{\circ} \mathrm{W}$ during the North Atlantic bloom experiment. Deep-Sea Res 40:197-212

Dam HG, Zhang X, Butler M, Roman MR (1995) Mesozooplankton grazing and metabolism at the equator in the central Pacific: implications for carbon and nitrogen fluxes. Deep-Sea Res 42:735-756

DeMott WR (1989) Optimal foraging theory as a predictor of chemically mediated food selection by suspension-feeding copepods. Limnol Oceanogr 34:140-154

Dolan JR (1991) Guilds of ciliate microzooplankton in the Chesapeake Bay. Estuar Coast Shelf Sci 33:137-152

Dolan JR, Gallegos CL, Moigis A (2000) Dilution effects on microzooplankton in dilution grazing experiments. Mar Ecol Prog Ser 200:127-139

Edwards ES, Burkill PH, Stelfox CE (1999) Zooplankton herbivory in the Arabian Sea during and after the SW monsoon, 1994. Deep-Sea Res 46:843-863

Fessenden L, Cowles TJ (1994) Copepod predation on phagotrophic ciliates in Oregon coastal waters. Mar Ecol Prog Ser 107:103-111

Froneman PW, McQuaid CD (1997) Preliminary investigation of the ecological role of microzooplankton in the Kariega Estuary, South Africa. Estuar Coast Shelf Sci 45:689-695

Gallegos CL (1989) Microzooplankton grazing on phytoplankton in the Rhode River, Maryland (USA): nonlinear feeding kinetics. Mar Ecol Prog Ser 57:23-34

Gasparini S, Castel J (1997) Autotrophic and heterotrophic nanoplankton in the diet of the estuarine copepods Eury- temora affinis and Acartia bifilosa. J Plankton Res 19: 877-890

Gaudy R, Pagano M, Cervetto G, SaintJean L, Verriopoulos G, Beker B (1996) Short term variations in feeding and metabolism of Acartia tonsa (pelagic copepod) in the Berre lagoon (France). Oceanol Acta 19:635-644

Gifford DJ (1988) Impact of grazing by microzooplankton in the northwest arm of Halifax Harbor, Nova Scotia. Mar Ecol Prog Ser 47:249-259

Gifford DJ (1991) The protozoan-metazoan trophic link in pelagic ecosystems. J Protozool 38:81-86

Gifford DJ, Dagg MJ (1988) Feeding of the estuarine copepod Acartia tonsa Dana: carnivory vs herbivory in natural microplankton assemblages. Bull Mar Sci 43:458-468

Gifford DJ, Dagg MJ (1991) The microzooplankton-mesozooplankton link: consumption of planktonic protozoa by the calanoid copepods Acartia tonsa Dana and Neocalanus plumchrus Murukawa. Mar Microb Food Webs 5:161-177

Halvorsen E, Pedersen OP, Slagstad D, Tande KS, Fileman ES, Batten SD (2001) Microzooplankton and mesozooplankton in an upwelling filament off Galicia: modelling and sensitivity analysis of the linkages and their impact on the carbon dynamics. Prog Oceangr 51:499-513

Hutchinson A (1981) Plankton studies in San Francisco Bay. III. Zooplankton species composition and abundance in the South Bay, 1978-1979. US Geological Survey OpenFile Report 81-132, Menlo Park, CA

Ianora A, Poulet SA, Miralto A (1995) A comparative study of the inhibitory effect of diatoms on the reproductive biology of the copepod Temora stylifera. Mar Biol 121: 533-539

Ivlev VS (1961) Experimental ecology of the feeding of fishes. Yale University Press, New Haven, CT

Jakobsen HH (2001) Escape response of planktonic protists to fluid mechanical signals. Mar Ecol Prog Ser 214:67-78

Jassby AD, Kimmerer WJ, Monismith SG, Armor C, Cloern JE, Powell TM, Schubel JR, Vendlinksi TJ (1995) Isohaline position as a habitat indicator for estuarine populations. Ecol Appl 5:272-289

Jonsson PR, Tiselius P (1990) Feeding behaviour, prey detection and capture efficiency of the copepod Acartia tonsa feeding on planktonic ciliates. Mar Ecol Prog Ser 60:35-44

Kimmerer WJ, Orsi JJ (1996) Changes in the zooplankton of the San Francisco Bay estuary since the introduction of the clam Potamocorbula amurensis. In: Hollibaugh JT (ed) San Francisco Bay. Pacific Division of the American Association for the Advancement of Science, San Francisco, p 403-424

Kiørboe T, Mohlenberg F, Hamburger K (1985) Bioenergetics of the planktonic copepod Acartia tonsa: relation between feeding, egg produciton and respiration, and composition of specific dynamic action. Mar Ecol Prog Ser 26:85-97

Kiørboe T, Saiz E, Viitasalo M (1996) Prey switching behavior in the planktonic copepod Acartia tonsa. Mar Ecol Prog Ser 143:65-75

Klein Breteler WCM, Schogt N, Baas M, Schouten S, Kraay GW (1999) Trophic upgrading of food quality by protozoans enhancing copepod growth: role of essential lipids. Mar Biol 135:191-198

Kleppel GS (1992) Environmental regulation of feeding and egg production by Acartia tonsa off southern California. Mar Biol 112:57-65

Kleppel GS (1993) On the diets of calanoid copepods. Mar Ecol Prog Ser 99:183-195

Kleppel GS, Hazzard SE (2000) Diet and egg production of the copepod Acartia tonsa in Florida Bay. II. Role of the nutritional environment. Mar Biol 137:111-121 
Kleppel GS, Holliday DV, Pieper RE (1991) Trophic interactions between copepods and microplankton: a question about the role of diatoms. Limnol Oceanogr 36:172-178

Kleppel GS, Burkart CA, Carter K, Tomas C (1996) Diets of calanoid copepods on the West Florida shelf: relationships between food concentration, food composition and feeding activity. Mar Biol 127:209-217

Kleppel GS, Burkart CA, Houchin L (1998) Nutrition and the regulation of egg production in the calanoid copepod Acartia tonsa. Limnol Oceanogr 43:1000-1007

Kurth R, Nobriga M (2001) Food habits of larval splittail. Interagency Ecological Program, Newsletter, Summer 2001, California Department of Water Resources, Sacramento, CA, p 40-42

Landry MR, Lorenzen CJ, Peterson WK (1994) Mesozooplankton grazing in the Southern California Bight. II. Grazing impact and particulate flux. Mar Ecol Prog Ser 115:73-85

Landry MR, Constantinou J, Kirshtein J (1995) Microzooplankton grazing in the central equatorial Pacific during February and August, 1992. Deep-Sea Res 42:657-671

Lechowicz MJ (1982) The sampling characteristics of electivity indices. Oecologia 52:22-30

Lehman JT (1976) The filter feeder as an optimal forager, and the predicted shapes of feeding curves. Limnol Oceanogr 21:501-516

Lehman PW (1996) Changes in chlorophyll a concentration and phytoplankton community composition with wateryear type in the upper San Francisco Bay estuary. In: Hollibaugh JT (ed) San Francisco Bay: the ecosystem. Pacific Division American Association for Advancement of Science, San Francisco, p 351-374

Lessard EJ, Murrell MC (1998) Microzooplankton herbivory and phytoplankton growth in the northwestern Sargasso Sea. Aquat Microb Ecol 16:173-188

Levinsen H, Turner JT, Nielsen TG, Hansen BW (2000) On the trophic coupling between protists and copepods in arctic marine ecosystems. Mar Ecol Prog Ser 204:65-77

Libourel Houde SE, Roman MR (1987) Effects of food quality on the functional ingestion response of the copepod Acartia tonsa. Mar Ecol Prog Ser 40:69-77

Lonsdale, DJ, Cosper EM, Kim WK, Doall M, Divadeenam A, Jonasdottir SH (1996) Food web interactions in the plankton of Long Island bays, with preliminary observations on brown tide effects. Mar Ecol Prog Ser 134:247-263

Marin V, Huntley ME, Frost B (1986) Measuring feeding rates of pelagic herbivores: analysis of experimental design and methods. Mar Biol 93:49-58

McManus GB, Ederington-Cantrell MC (1992) Phytoplankton pigments and growth rates and microzooplankton grazing in a large temperate estuary. Mar Ecol Prog Ser 87:77-85

Menden-Deuer S, Lessard EJ (2000) Carbon to volume relationships for dinoflagellates, diatoms, and other protist plankton. Limnol Oceanogr 45:569-579

Meng L, Orsi JJ (1991) Selective predation by larval striped bass on native and introduced copepods. Trans Am Fish Soc 120:187-192

Merrell J, Stoecker D (1998) Differential grazing of protozoan microplankton by developmental stages of the calanoid copepod Eurytemora affinis Poppe. J Plankton Res 20: 289-304

Miller CA, Penry DL, Glibert PM (1995) The impact of trophic interactions on rates of nitrogen regeneration and grazing in Chesapeake Bay. Limnol Oceanogr 40:1005-1011

Miralto A, Barone G, Romano G, Poulet SA and 7 others (1999) The insidious effect of diatoms on copepod reproduction. Nature 402:173-176
Moyle PB, Herbold B, Stevens DE, Miller LW (1992) Life history and status of delta smelt in the Sacramento-San Joaquin estuary, California. Trans Am Fish Soc 121:67-77

Murrell MC, Hollibaugh JT (1998) Microzooplankton grazing in northern San Francisco Bay measured by the dilution method. Aquat Microb Ecol 15:53-63

Nejstgaard JC, Gismervik I, Solberg PT (1997) Feeding and reproduction by Calanus finmarchicus, and microzooplankton grazing during mesocosm blooms of diatoms and the coccolithophore Emiliania huxleyi. Mar Ecol Prog Ser 147:197-217

Nejstgaard JC, Hygum BH, Naustvoll LJ, Bamstedt U (2001a) Zooplankton growth, diet and reproductive success compared in simultaneous diatom- and flagellate-microzooplankton-dominated plankton blooms. Mar Ecol Prog Ser 221:77-91

Nejstgaard JC, Naustvoll LJ, Sazhin A (2001b) Correcting for underestimation of microzooplankton grazing in bottle incubation experiments with mesozooplankton. Mar Ecol Prog Ser 221:59-75

Nichols FH, Thompson JK, Schemel LE (1990) Remarkable invasion of San Francisco Bay (California, USA) by the Asian clam Potamocorbula amurensis. 2. Displacement of a former community. Mar Ecol Prog Ser 66:95-101

Nival P, Nival S (1976) Particle retention efficiencies of an herbivorous copepod, Acartia clausi (adult and copepodite stages): effects on grazing. Limnol Oceanogr 21:24-38

Obrebski S, Orsi JJ, Kimmerer WJ (1992) Long-term trends in zooplankton distribution and abundance in the Sacramento-San Joaquin estuary of California. California Interagency Ecological Studies Program Technical Report 32. Sacramento, CA

Ohman MD, Runge JA (1994) Sustained fecundity when phytoplankton resources are in short supply: omnivory by Calanus finmarchicus in the Gulf of St. Lawrence. Limnol Oceanogr 39:21-36

Orsi JJ, Mecum WJ (1986) Zooplankton distribution and abundance in the Sacramento-San Joaquin Delta in relation to certain environmental factors. Estuaries 9:326-339

Pomeroy LR (1974) The ocean's food web: a changing paradigm. BioScience 24:499-504

Porter KG, Sherr EB, Sherr BF, Pace M, Sanders RW (1985) Protozoa in planktonic food webs. J Protozool 32:409-415

Poulet SA, Ianora A, Miralto A, Meijer L (1994) Do diatoms arrest embryonic development in copepods? Mar Ecol Prog Ser 111:79-86

Pyke GH (1984) Optimal foraging theory: a critical review. Annu Rev Ecol Sys 15:523-575

Richman S, Heinle DR, Huff R (1977) Grazing by adult estuarine calanoid copepods of the Chesapeake Bay. Mar Biol 42:69-84

Rollwagen Bollens GC, Landry MR (2000) The biological response to iron fertilization in the eastern equatorial Pacific (IronEx II). II. Mesozooplankton abundance, biomass, depth distribution and grazing. Mar Ecol Prog Ser 201:43-56

Ruiz AJ, Franco K, Villate F (1998) Microzooplankton grazing in the Estuary of Mundaka, Spain, and its impact on phytoplankton distribution along the salinity gradient. Aquat Microb Ecol 14:281-288

Sanders RW, Wickham SA (1993) Planktonic protozoa and metazoa: predation, food quality and population control. Mar Microb Food Webs 7:197-223

Sautour B, Artigas LF, Delmas D, Herbland A, Laborde P (2000) Grazing impact of micro- and mesozooplankton during a spring situation in coastal waters off the Gironde estuary. J Plankton Res 22:531-552 
Sherr BF, Sherr EB, Andrew TL, Fallon RD, Newell SY (1986) Trophic interactions between heterotrophic Protozoa and bacterioplankton in estuarine water analyzed with selective metabolic inhibitors. Mar Ecol Prog Ser 32:169-179

Sherr EB, Sherr BF (1985) Importance of heterotrophic protozoa in estuarine food webs. Estuaries 8:35

Sherr EB, Sherr BF (1994) Bacterivory and herbivory: key roles of phagotrophic protists in pelagic food webs. Microb Ecol 28:223-235

Sherr EB, Sherr BF, Paffenhöfer GA (1986) Phagotrophic protozoa as food for metazoans: a 'missing' trophic link in marine pelagic food webs? Mar Microb Food Webs 1: $61-80$

Sherr EB, Caron DA, Sherr BF (1993) Staining of heterotrophic protists for visualization via epifluorescence microscopy. In: Kemp PF, Sherr BF, Sherr EB, Cole JJ (eds) Handbook of methods in aquatic microbial ecology. Lewis Publishers, Boca Raton, FL, p 213-227

Stoecker DK, Capuzzo JM (1990) Predation on protozoa: its importance to zooplankton. J Plankton Res 12:891-908

Stoecker DK, Egloff DA (1987) Predation by Acartia tonsa Dana on planktonic ciliates and rotifers. J Exp Mar Biol Ecol 110:53-68

Strom SL (2000) Bacterivory: interactions between bacteria and their grazers. In: Kirchman DL (ed) Microbial ecology of the oceans. Wiley-Liss, New York, p 251-286

Strom SL, Welchmeyer NA (1991) Pigment-specific rates of phytoplankton growth and microzooplankton grazing in the open subarctic Pacific Ocean. Limnol Oceanogr 36: $50-63$

Tamigneaux E, Mingelbier M, Klein B, Legendre L (1997) Grazing by protists and seasonal changes in the size structure of the protozooplankton and phytoplankton in a temperate nearshore environment (western Gulf of St. Lawrence, Canada). Mar Ecol Prog Ser 146:231-247

Tett P, Wilson H (2000) From biogeochemical to ecological models of marine microplankton. J Mar Syst 25:431-446

Editorial responsibility: Barry and Evelyn Sherr (Contributing Editors), Corvallis, Oregon, USA
Tiselius P (1989) Contribution of aloricate ciliates to the diet of Acartia clausi and Centropages hamatus in coastal waters. Mar Ecol Prog Ser 56:49-56

Vanderploeg HA, Scavia D (1979a) Calculation and use of selectivity coefficients of feeding: zooplankton grazing. Ecol Modeling 7:135-149

Vanderploeg HA, Scavia D (1979b) Two electivity indices for feeding with special reference to zooplankton grazing. J Fish Res Board Can 36:362-365

Verity PG, Paffenhöfer GA (1996) On assessment of prey ingestion by copepods. J Plankton Res 18:1767-1779

Verity PG, Stoecker DK, Sieracki ME, Nelson JR (1993) Grazing, growth and mortality of microzooplankton during the 1989 North Atlantic spring bloom at $47^{\circ} \mathrm{N}, 18^{\circ} \mathrm{W}$. DeepSea Res 40:1793-1814

Vincent D, Hartmann HJ (2001) Contribution of ciliated microprotozoans and dinoflagellates to the diet of three copepod species in the Bay of Biscay. Hydrobiologia 443: 193-204

White JR, Roman MR (1992) Egg production by the calanoid copepod Acartia tonsa in the mesohaline Chesapeake Bay: the importance of food resources and temperature. Mar Ecol Prog Ser 86:239-249

Wiadnyana NN, Rassoulzadegan F (1989) Selective feeding of Acartia clausi and Centropages typicus on microzooplankton. Mar Ecol Prog Ser 53:37-45

Wilson DS (1973) Food size selection among copepods. Ecology 54:909-914

Wong RLJ, Cloern JE (1982) Plankton studies in San Francisco Bay. IV. Phytoplankton abundance and species composition January 1980-February 1981. US Geological Survey Open File Report 82-443, April 1982

Zar JH (1996) Biostatistical analysis, 3rd edn. Prentice Hall, Upper Saddle River, NJ

Zeldis J, James MR, Grieve J, Richards L (2002) Omnivory by copepods in the New Zealand Subtropical Frontal Zone. J Plankton Res 24:9-23

Submitted: September 15, 2002; Accepted: March 18, 2003 Proofs received from author(s): July 23, 2003 